\title{
Margarida Andreatta e a conformação da Arqueologia Histórica Paulistana
}

\author{
Rafael de Abreu e Souza*
}

\section{SOUZA, R.A. Margarida Andreatta e a conformação da Arqueologia}

Histórica Paulistana R. Museu Arq. Etn., São Paulo, n. 22: 157-180, 2012.

Resumo: Este trabalho tem como objetivo ressaltar o papel da professora Margarida Davina Andreatta no escopo do fortalecimento da Arqueologia Histórica (e Urbana) na cidade de São Paulo a partir da compreensão de sua trajetória intelectual e do campo no qual estava inserida. Margarida participou da formação de toda uma leva de pesquisadores que atuaram em São Paulo com leituras, destarte seguindo linhas diferenciadas, possuidoras de elos comuns, como, por exemplo, a não utilização da classificação da Tradição cerâmica "neobrasileira" e sua escolha por determinados métodos de campo.

Palavras-chaves: Margarida Andreatta, Arqueologia Histórica, São Paulo

\section{Introdução}

Arqueologia Histórica não precisa mais de afirmação, apesar da luta por sua realização no escopo urbano, frente às dinâmicas de transformação da cidade-mundo (Augé 1994) que é São Paulo. Neste sentido, faz-se importante refletir sobre o processo de formação da disciplina na cidade a partir da figura da professora Margarida Andreatta, pesquisadora do Museu Paulista e do Museu de Arqueologia e Etnologia da Universidade de São Paulo, referindo-se ao capital cultural e social (Bourdieu 2001) de trajetória, com preferências e aspirações, com sentido, ritmo e direção (Velho 2008).

$\left(^{*}\right)$ Doutorando em Arqueologia, Museu de Arqueologia e Etnologia, USP e em Ambiente e Sociedade pelo NEPAM/ UNICAMP.
As sínteses produzidas em torno da história da Arqueologia Histórica no Brasil e no Cone Sul tem dado pouca atenção às pesquisas da professora Margarida e ao trabalho que desenvolveu no país. Compreender o contexto de sua formação e as redes de relações que marcaram sua formação possibilita pensar criticamente sua trajetória intelectual e sua função a partir de laços orgânicos que a vinculavam a comunidade (Said 2003). Voz solitária em relação a certas temáticas, representou o que professava por meio de trabalhos e intervenções (Said 2003) de cunho mais prático, mais "empírico" do que "teórico" (Johnson 1999; Reis 2003). Quero dizer que as contribuições de Andreatta deram-se efetivamente associadas ao trabalho de escavação em locais com presença de vestígios passíveis de leitura arqueológica.

Em geral, Margarida Andreatta é associada às pesquisas urbanas em São Paulo nos anos 
1980 e, destarte produção de estudos sobre a Arqueologia Histórica latino-americana (Lima 1993; Zanettini e Cazzetta 1993; Funari 1997; Zarankin 2007; Symanski 2009), faz falta investigações mais aprofundadas que auxiliem na compreensão de como os pesquisadores tiveram contato e implantaram perspectivas da Arqueologia Histórica no país, sem advir de "escolas" ou instituições que tinham na área uma possibilidade clara de abordagem. Este artigo aponta, ainda, à correlação, pouco explorada, entre "Arqueologia Pré-Histórica" e "Histórica", como a prática científica insistiu em dissociar (Prous 1992; Zanettini e Cazzetta 1993; Barreto 1999).

A investigação da trajetória intelectual da professora Margarida permitiu não apenas encontrar pistas de como se consolidou a Arqueologia Histórica em São Paulo, mas de como se formou na cidade uma vertente de atuação bastante marcada por suas prerrogativas, afastada das pronapianas e exímia conhecedora das escavações etnográficas. Além disso, possibilitou notar que a Arqueologia Histórica pouco dispunha de espaços para publicações. Como lembra Marcos Albuquerque (1992), "os primeiros desbravadores desta Arqueologia dificilmente encontravam espaço em simpósios ou congressos para apresentarem o resultado de suas pesquisas”. As publicações primeiras da Arqueologia Histórica no Brasil encontram-se pulverizadas em revistas de patrimônio, arquitetura, de divulgação científica e outras cujo foco não era Arqueologia. Se isto indica relações com outras áreas do conhecimento, faz clara alusão a pouca aceitação da Arqueologia Histórica no campo brasileiro (Lima 1993).

Margarida forma-se em Geografia e História pela Faculdade Católica de Filosofia de Curitiba, mais tarde PUC do Paraná, entre 1955 e 1957. Sob os cuidados dos Irmãos Maristas, a FCFC seguia a mesma orientação ideológica (o ideário católico) da Faculdade de Filosofia, Ciências e Letras do Paraná (mais tarde UFPR), com presença do laicato católico (Campos 2010). Isto resulta das amistosas relações entre Estado e Igreja, entre 1930 e 1940, em especial pela aproximação de intelectuais como Manoel Ribas e Loureiro Fernandes na formação dos cursos superiores paranaenses (Campos 2010;
2011). O envolvimento de Fernandes caracteriza a geração de intelectuais brasileiros preocupados com a construção de uma identidade nacional e a preservação do patrimônio cultural através da formação profissional (Maranhão 2006).

No curso, Margarida teve aulas de Geografia Física, Geografia Humana, Geografia do Brasil, Etnografia, Antropologia, História da Antiguidade e Idade Média, História Moderna, do Brasil, da América e Contemporânea, além de disciplinas como Etnografia Brasileira e Língua Tupi (Carvalho 2010). História e Geografia marcadamente de caráter evolucionista foram ministradas em cursos por inúmeros professores, dentre eles Loureiro Fernandes (Campos 2011).

Este corpo docente ajudou a compor o capital cultural dos futuros alunos e indica a presença marcante de Fernandes antes da entrada propriamente dita de Margarida na Arqueologia. Mais tarde, graças a ele, Margarida pode realizar cursos e estudos pelo Museu do Homem de Paris, pela Associação de Arqueólogos Portugueses e em locais na Espanha e Itália (Andreatta 2005).

Margarida inicia seus trabalhos de arqueologia, graduanda, no Centro de Estudos e Pesquisas Arqueológicas, onde se formaram arqueólogos atuariam no ambiente urbano/histórico em seus respectivos estados como Marcos Albuquerque, no Pernambuco, e Ondemar Dias, no Rio. Estas primeiras experiências direcionam a entrada de Margarida no universo da Arqueologia a partir dos sambaquis.

É importante ressaltar que com a criação do CEPA deu-se início a uma programação intensiva de cursos ministrados por arqueólogos estrangeiros, como Joseph Emperaire e Wesley Hurt (Lima 1999/2000). Hurt inaugura pesquisas sistemáticas nos sambaquis de Paranaguá, com atenção à estratigrafia dos sítios e suas ordenações cronológicas. A partir de 1956, o casal Emperaire assume as escavações em outros sambaquis das bacias de Paranaguá e Antonina, contando com os discípulos Oldemar Blasi, Margarida Andreatta e Maria José Menezes (Lima 1999/2000).

A equipe escava sambaquis famosos como o Toral 51 e o Ilha das Rosas (Anette e Andreatta, 1976; Schmitz 2009), no qual o Pe. Rohr 
desenvolveu a técnica da "cimentação" para o recolhimento de esqueletos (Albuquerque 1986). Das aulas práticas no sambaqui participaram também José Proenza Brochado, Ondemar Dias, Igor Chmyz, Celso Perota, Maria Beltrão e Marcos Albuquerque (Schmitz et al. 1989).

Margarida insere-se, deste modo, nas ações das missões arqueológicas francesas levadas a cabo no Brasil, nascentes do interesse europeu em pesquisar as culturas pré-históricas latino-americanas menos conhecidas, no âmbito do “americanismo" francês (Barreto 1999). Marcadamente influenciadas por Leroi-Gourhan e pelo casal Emperaire, a perspectiva das tipologias e culturas arqueológicas influencia os trabalhos de Margarida em termos. Apesar de utilizar as abordagens de que o registro deve ser priorizado sobre a escavação e que nesta, as estruturas devem predominar sobre a estratigrafia (Alberioni 2003), adapta, mais tarde, estas prerrogativas ao contexto urbano, no qual a sucessão de camadas demanda uma leitura estratigráfica primorosa.

Em 1957, bolsas da Capes possibilitam estágio dos alunos Waldemiro Bley Jr., Margarida Davina Andreatta e Maria da Conceição de Moraes Coutinho na escavação do sambaqui do Guaraguaçu, um dos maiores do Paraná, durante o primeiro ano do curso de Arqueologia oferecido pelo CEPA. Em 1958, outras quatro bolsas da Capes permitem a participação, no mesmo sambaqui, dos estudantes Margarida Andreatta, Maria José Menezes, William Routh e Maria da Conceição. Coordenado pelo casal Emperaire, o Guaraguaçu foi sistematicamente escavado entre 1957 e 1961, composto por dois sambaquis superpostos (A e B) de onde foram retirados mais de 100 esqueletos humanos.

Maria Menezes e Margarida, em 1968, publicam estudos sobre os sepultamentos com dados paleodemográficos e antropométricos.

Nesta mesma época, Margarida participa da escavação de outros sítios, com etapas supervisionadas por Hurt. Entre agosto e outubro de 1958, com Oldemar Blasi, os estudantes José Rauth, Margarida e Maria da Conceição escavam o sítio-escola do sambaqui do Macedo, também em Paranaguá. Os estudos levados a cabo por Hurt e Blasi no Macedo deram particular atenção ao processo de edificação do sambaqui, uma "pirâmide truncada", em alusão aos mounds norte-americanos (Guimarães 2003).

Em 1959, Loureiro Fernandes funda a "Secção Regional da Associação Brasileira de Antropologia”, em Paranaguá, durante sua atuação como presidente da ABA (1957 e 1959). A reunião, que contou com a presença de Margarida, resultou na somatória das experiências do CEPA, do Departamento de Antropologia e da Seção de Antropologia, Etnologia e Antropogeografia do Instituto de Pesquisas da Faculdade de Filosofia da Federal do Paraná (Chmyz 2006: 187).

Com as escavações do sambaqui do Machado, em Alexandra, Paranaguá, Margarida dá início (Andreatta 1960) a publicações voltadas à análise da fauna malacológica, sua primeira especialidade. Nos anos 1970, publica, com o Pe. Rohr, estudos sobre o sambaqui do Tapera, com a apresentação do material osteodondomalacológico do sítio no IIIo Simpósio de Arqueologia. Desde 1958 (e até os anos 1980), Rohr, com quem Margarida viria a trabalhar, aluno de Annette Emperaire, dá início ao programa de escavações em sítios litorâneos que originaria o Museu do Homem do Sambaqui, privilegiando abordagens verticais e superfícies amplas, buscando dados sobre os usos do espaço, particularmente o funerário (Lima 1999/2000). Em 1977, durante o II Simpósio de Arqueologia da Área do Prata e Adjacências, em São Leopoldo, RS, apresenta sugestões para terminologia do material arqueológico em dente, chifre e osso, num dos primeiros esforços do tipo para os sambaquis do país.

Durante os anos 1960, Margarida atuou ainda em outros sambaquis do Paraná e Santa Catarina. Seus estudos giraram em torno da problemática, corrente entre os anos $1950 \mathrm{e}$ 1980, de tentativas de agrupamentos regionais dos sambaquis, apoiadas na sistematização das diferenças e das semelhanças de sua cultura material (Tenório 2004).

É assim que, entre junho e setembro de 1969, Margarida participa da primeira etapa de escavações do sítio Armação do Sul, um "sítio pré-cerâmico raso", junto do Pe. Rohr e das estagiárias Zulmara Sauner e Kátia Giordano, do CEPA. Oitenta e seis sepultamentos foram 
encontrados, além de "covas culinárias", a partir do método de estaqueamento em quadrículas de $2 \times 2 \mathrm{~m}$ escavadas em níveis artificiais de 10 cm (Schmitz et al. 1993). Um dos indivíduos foi encontrado com mais de 50 pontas de projétil sobre o peito (Rohr e Andreatta 1969). A importância do sítio da Armação do Sul na formação de Margarida é grande: marca o primeiro contato da arqueóloga com um contexto histórico, uma vez que se trata de um sítio multicomponencial no qual foram registradas estruturas e coletados materiais cerâmicos e metálicos relacionados a uma armação de baleia do século XVIII (Comerlato 2003).

Os trabalhos com o casal Emperaire, intensificados na década de 60, resultaram na formação no âmbito da chamada "Escola Francesa" (Reis 2007). Também graças a eles, Andreatta esteve sobre os auspício de Leroi-Gourhan, de 1962 a 1965, realizando estágio no Centre de Recherche Prehistoriques et Protohistoriques do Museu do Homem. O estágio visava pesquisas em sítios arqueológicos, com escola de campo em alguns deles como Arcy-sur-Cure. Durante estes anos, participou dos trabalhos na região de La Quina, na biblioteca e na seção de restauração e conservação de coleções etnográficas do Museu. Tem início a influência de Leroi-Gourhan sob a arqueóloga, "verdadeira imagem do humanista moderno" como ela mesma definiria (1965).

As escavações na escola de campo de Arcy-sur-Cure, em Yonne, tiveram composição mais ou menos fixa, incluindo Leroi-Gourhan como coordenador por anos. A esta equipe, como o próprio Leroi-Gourhan colocou, se juntariam, a cada ano, diversos estagiários franceses e estrangeiros (Leroi-Gourhan 1961). Com eles, Margarida é imersa na metodologia clássica de escavação horizontal máxima, onde cada artefato era identificado em três dimensões, fotografado, inventariado e classificado.

Durante a estadia na França, a 22 de maio 1963, a reunião da Societé des Americanistes nomeou Margarida membro, apresentada por Annette Emperaire e Lehmann, em mesa sob a presidência de Claude Lévi-Strauss, após palestra de Annette sobre o quadro cronológico da pré-história do Brasil meridional. Mais tarde, entre

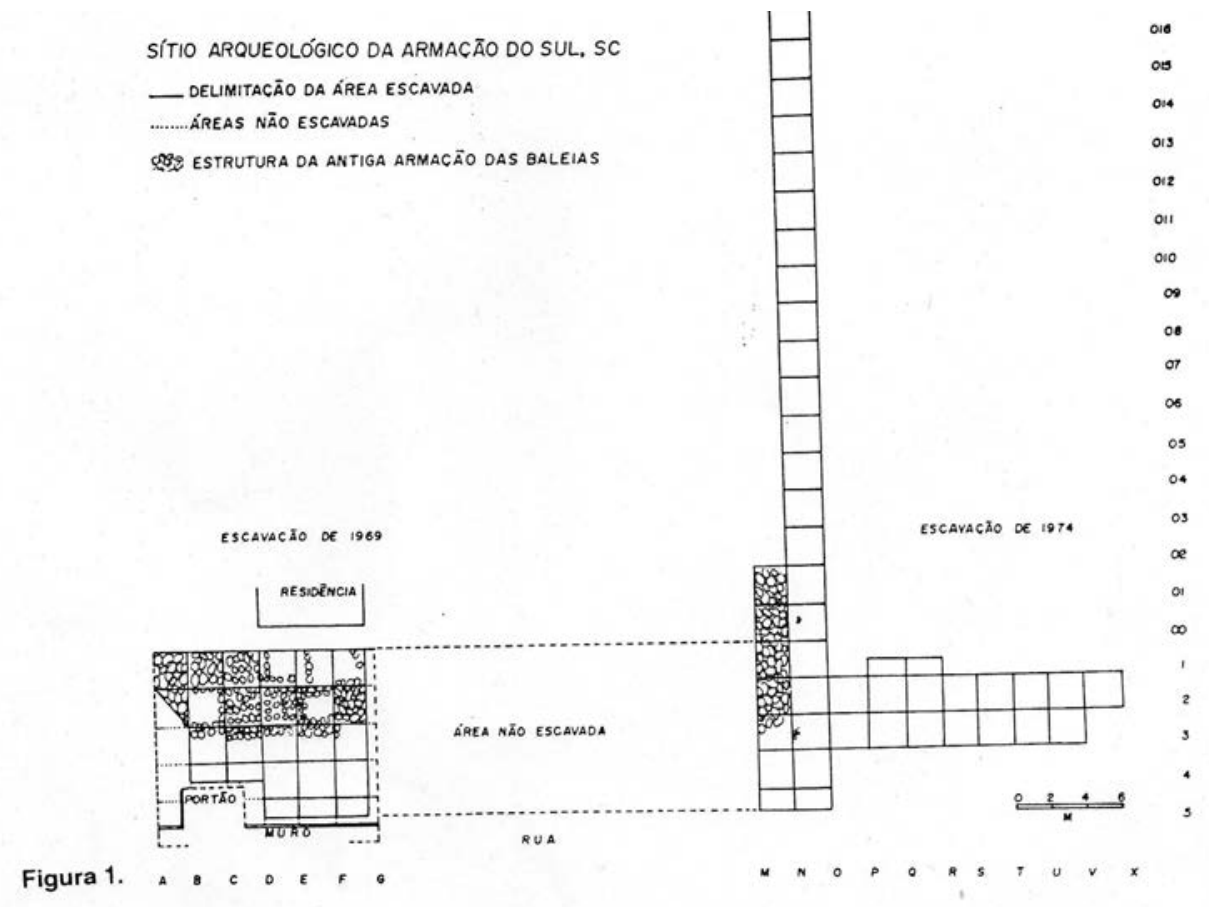

Fig. 1: Escavações no sambaqui da Armação do Sul (Schmitz et al 1993) 
1964 e 1965, Andreatta fez parte do curso ministrado por Leroi-Gourhan intitulado Étude sur la téchnique actuelle de l'archeologie, reafirmando a total imersão no convívio e aprendizado com a metodologia das escavações em superfícies amplas, que utilizava trincheiras como ataque vertical para compreensão da estratigrafia.

As escavações em La Quina, um sítio neandertal localizado no sudoeste da França, na região de Charente, proporcionaram a Margarida o contato com uma tecnologia lítica diferente daquela presente na América. O sítio, com datas de 33 mil anos a. C., foi escavado por Germaine Henri-Martin entre 1950 e 1960, interpretando-o a partir das mudanças tecnológicas relacionadas às diferentes ocupações (Henri-Martin 1965). A metodologia utilizava a divisão em setores nomeados por letras maiúsculas do alfabeto, algo que estará presente em diversos trabalhos da professora Margarida.

Também nesta época, Margarida participa de campanha dirigida pelo tenente-coronel Manuel Afonso do Paço, em Portugal, que dirigiu investigações arqueológicas no Castro de Vila Nova de São Pedro, um povoado calcolítico (Vas- concellos 1964: 873) com estrutura defensiva central e muralhas circundantes (Pereira 2011). $\mathrm{O}$ acervo era composto por artefatos de metalurgia, ossos, marfim e líticos lascados (Paço 1960).

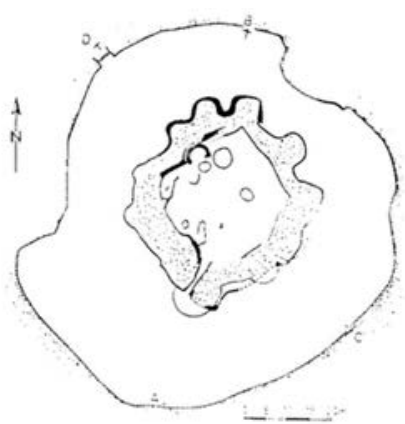

Fig. 3: Planta baixa do Castro de Vila Nova de São Pedro (Paço 1960)

Entre 1965 e 1970, Andreatta atuou em sítios paleocristãos do norte de Portugal, com destaque para as ocupações na Citânia de Briteiros. Descoberto no século XIX pelo arqueólogo português Francisco Sarmento, Citânia de Briteiros

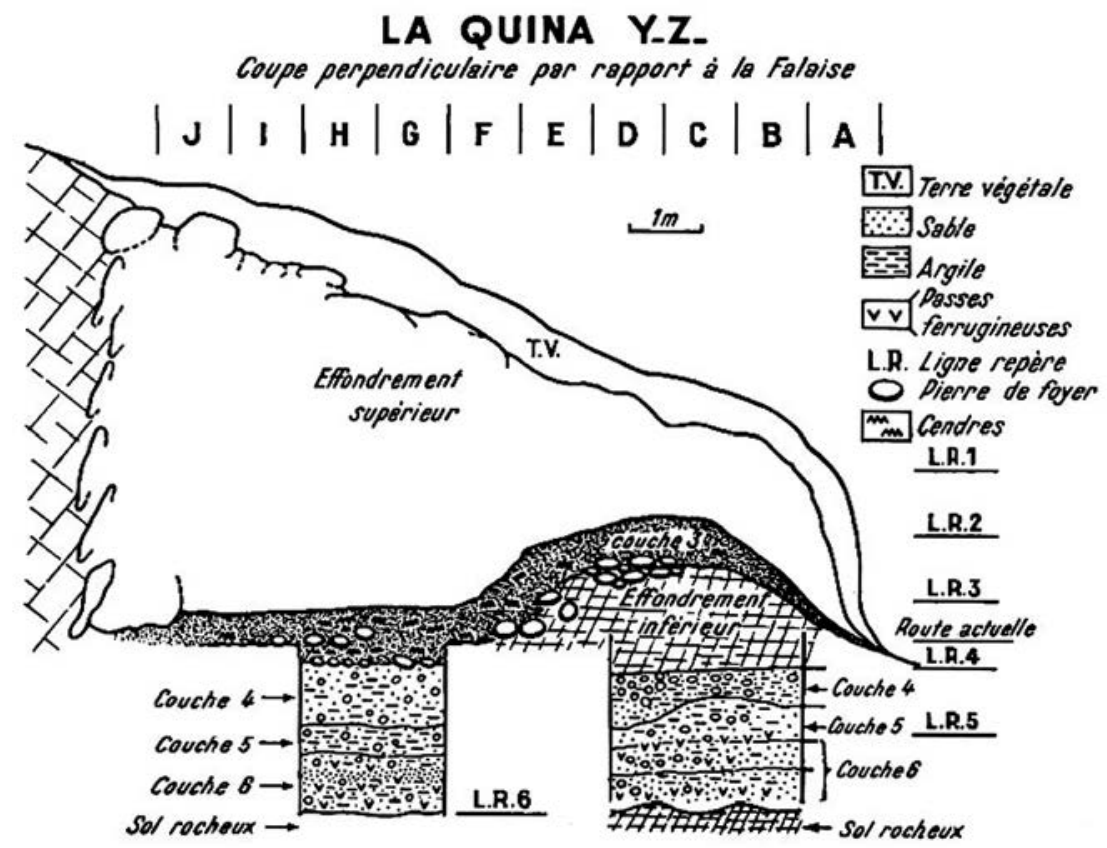

Fig. 2: Corte estratigráfico de La Quina (Germaine Henry-Martin, 1965) 
é um sítio da Idade do Ferro, castro do noroeste da Península Ibérica igualmente amuralhado.

Em 1966, Margarida participa, também em Portugal, das escavações do Balineu lusitano-romano da Egitânia, termas de uma vila romana, coordenadas pelo arqueólogo português Fernando de Almeida - diretor do Museu Natural de Arqueologia entre 1966 e 1973 (Raposo 2003). Almejando compreender a história da ocupação do local, forma abertos pequenos cortes em estratigrafia para evidenciar o edifício arruinado do século I abaixo da grande camada de entulho resultante da invasão dos Francos no século III; os cortes de $1 \mathrm{~m}^{2}$ apresentaram um complexo perfil com 12 camadas distintas e procuraram traduzir "a história relatada neste pequeno corte testemunho" (Almeida e Ferreira 1966). Inúmeras eram as camadas de descarte de terra sigilita e de aterros sucessivos.
Entre 1968 e 1969 acontecia o curso de Aperfeiçoamento em Arqueologia e o de Aperfeiçoamento em Antropologia Cultural na Faculdade de Filosofia de São Leopolodo, ministrado por Mentz Ribeiro desde 1965, do qual participaram José Brochado, Pedro Inácio Schmitz, Maria Beltrão, Maria José Menezes, Igor Chmyz, etc. A foto abaixo, tirada no encontro em 1968, mostra, junto a uma mesa com material lítico lascado, Margarida Andreatta acompanhada do Pe. Rohr, do Pe. Schmitz, do Irmão Marista Guilherme Naue e do historiador Danilo Lazarotto.

Até os anos 1970, quando Margarida efetivamente assumiu a coordenação de projetos sistemáticos de arqueologia, realizou trabalhos e fez contato com inúmeros (dos poucos) arqueólogos que atuavam no país, em especial entre São Paulo e o Rio Grande do Sul. As pesquisas

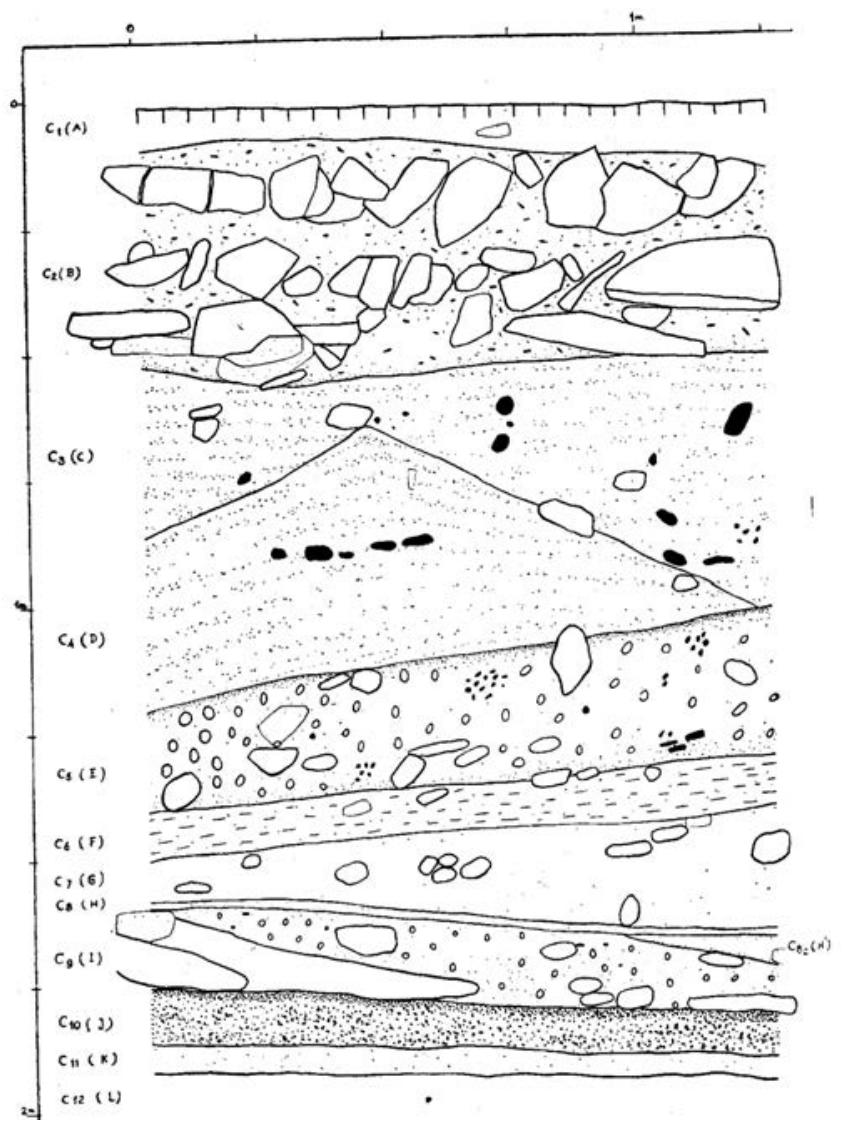

Fig. 4: Perfil estratigráfico do Balineu da Egitânia (Almeida e Ferreira, 1966) 
sobre os sambaquis, seu primeiro aporte, não foram de todo abandonadas, uma vez que entre 1972 e 1979, já coordenadora do curso de Antropologia da Universidade Federal de Santa Catarina, participa, de projeto com Anamaria Beck, das escavações de sambaquis como o Morro do Ouro, em Joinville.

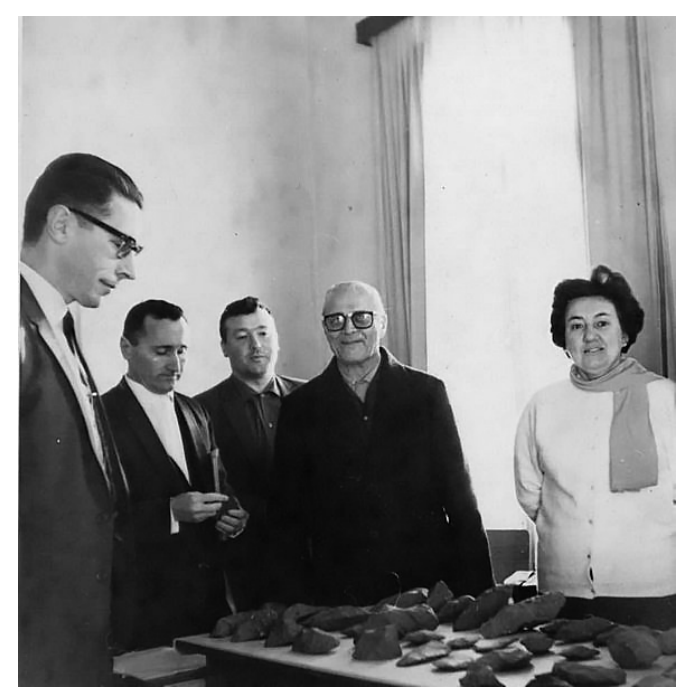

Fig. 5: Schmitz, Naue, Lazarotto, Rohr e Andreatta (IAP, 2012)

O projeto integrado de pesquisa composto por Beck, Gerusa Duarte, Andreatta, Edson Araújo e Maria José Reis, intitulado "O povoamento pré-histórico de Santa Catarina", objetivou compreender a ocupação pré-histórica do "espaço territorial", buscando delinear terminologias e conceitos ainda incipientes na Arqueologia Brasileira ("unidade espacial", "unidade arqueológica”, "sítio", "continuidade espacial" e "continuidade temporal"). A Margarida fica a incumbência de estudar a "ocupação pré-histórica do litoral sul de Santa Catharina” (Beck et al 1971). Os estudos procuraram também fortalecer e dinamizar o papel do Museu de Antropologia da UFSC.

As experiências de docência e vínculos institucionais consolidam-se nos anos 1970. Assume a coordenação do curso de Antropologia da UFSC, entre 1970 e 1973, em momento crucial para a Antropologia de catarinense (Reith 2007). Em 1972, ministra aulas na Especialização em Antropologia Social da UFPR, cerne do futuro mestrado em Antropologia. Estas posições, políticas, possibilitam o projeto com Beck.

Também em 1972, Margarida torna-se arqueóloga do Museu Paulista da USP. Sua entrada insere-se no momento de reestruturação da Arqueologia no Museu, iniciado nos anos 1960 quando Luciana Pallestrini deixa o Instituto de Pré-História. Este "novo fôlego" (Wichers 2012) cria um Setor de Arqueologia nos anos 1970 e resulta na entrada não apenas de Margarida, mas de Silvia Maranca e Agueda Vilhena, reestruturando a Arqueologia na instituição a partir da efetivação do primeiro programa continuado do estado de São Paulo, o Projeto Paranapanema (Wichers 2012).

Neste momento, com Niéde Guidon, participa dos trabalhos na Toca do Meio, no Parque da Serra da Capivara, no Piauí, sítio com pinturas rupestres, líticos com evidências de uso e fogueiras bastante antigas (Guidon e Andreatta 1980; Prous 2002). Segundo Margarida, o sítio continha, ainda, um componente histórico: edificações de adobe associadas à cultura sertaneja piauiense. $\mathrm{O}$ projeto coordenado por Guidon estava vinculado ao MAE e ao MP.

Durante o II Encontro Interregional de Cientistas Sociais do Brasil, em 1974 (Garanhuns, PE), Margarida apresenta os resultados das escavações do sítio Lapa Vermelha IV, em Lagoa Santa, Minas Gerais, fruto de sua atuação na missão franco-brasileira liderada pelos Emperaire entre 1971 e 1973. Influenciada pelas pesquisas anteriores de Hurt e Blasi, Annette Emperaire constitui uma missão para Lagoa Santa, da qual participam importantes nomes da Arqueologia Brasileira como André Prous e Agueda Vialou. O sítio ficaria famoso pela localização do crânio de Luzia, mais tarde alvo dos estudos de Walter Neves (Neves e Piló 2008). A participação na missão em Minas colocaria Margarida em maior contato com abrigos, grutas e arte rupestre, como fica claro no artigo que publica em 1975, com Annette e outros arqueólogos. Já havia, todavia, escavado outro abrigo, o do Wôbeto, no planalto paranaense, também com Annette (Andreatta 1968).

Em 1975, o Museu Paulista oferece o curso de extensão universitária "Introdução à Museologia”, no qual Margarida ministra a disciplina 
"A importância da peça arqueológica em seu contexto original, com ênfase preferencial em Museologia”. Em 1976, com a continuidade do curso, ministra a disciplina "Museu e Arqueologia I". Este teria sido um dos primeiros esforços em direção a musealização do patrimônio arqueológico paulista (Wichers 2012).

Margarida passou a atuar, então, por 16 anos, como pesquisadora do Museu Antropológico da UFG, a partir da coordenação do Projeto Anhanguera (em conjunto a Luciana Pallestrini, que atuou apenas entre 1975 e 1976). O projeto, interdisciplinar, buscava reconstituir quadros humanos e geográficos da região, realizando prospecções e escavações (de sítios pré-históricos e históricos), levantamentos de pinturas, estudo de material arqueológico, datações e formação de equipe (Andreatta 1985).

A partir de 1975, o Projeto Anhanguera, desenvolvido pelo Museu Paulista e pelo Museu Antropológico, centrou-se na escavação de diversos sítios líticos e cerâmicos (nos quais são realizados os primeiros estudos sobre os "vasos de bojo duplo" arqueológicos [Andreatta 1982]); foram cadastrados, por outro lado, os primeiros sítios históricos localizados pela própria Margarida. $\mathrm{O}$ projeto levantou 33 sítios, escavados por "decapagens em amplas superfícies, com a execução de trincheiras e perfis como indicadores dos diferentes níveis e composição dos solos" (Andreatta 198; Schmitz e Barbosa 1985). As campanhas de escavação utilizaram o sub-quadriculamento, metro a metro, com decapagens e evidenciações de vestígios a partir de sua sucessão. Soma-se a esta metodologia a utilização de trincheiras destinadas a "verificação da estratigrafia junto às estruturas habitacionais; à coleta de sedimentos para análise do solo; e ao traçado dos perfis" (Andreatta 1977: 54). As trincheiras foram uma forma clássica de intervenção arqueológica que passou a ser bastante utilizada quando das escavações nas Casas Bandeiristas em São Paulo. Deste projeto, participaram, como estagiárias, Márcia Angelina Alves, Dilamar Cândida Martins e Margareth Souza. As duas últimas desenvolveram estudos de pós-graduação sob orientação da professora Margarida.

Os sítios arqueológicos históricos, de caráter urbano (como a cidade de Santa Cruz de Goiás, fundada no século XVIII), sofreram levantamento cadastral topográfico das habitações, com observação das técnicas de construção em adobe, dos muros e fundações de pedra e do grau de conservação (Andreatta 1985). No geral, o projeto acabou sendo uma das primeiras pesquisas sistemáticas sobre a ocupação do Brasil Central e é referencia para os estudos das ocupações indígenas em aldeias circulares (Wüst e Barreto 1999; Oliveira 2005).

Entre 1977 e 1982, Andreatta desenvolveu doutorado em Antropologia Social na USP, em torno dos padrões de assentamento pré-coloniais, no âmbito do projeto que coordenava em Goiás, sob orientação de Pallestrini. A partir dos estudos do sítio Bonsucesso, em Nazário, Margarida teceu considerações sobre a evidenciação de padrões de povoamento interpretando as chamadas "manchas pretas" como espaços habitacionais de uma grande aldeia pré-histórica. As relações do ambiente circundante com a organização dos espaços habitacionais é ponte para a interpretação "arqueo-etnológica" em torno da ocupação humana em ambientes diversos (Andreatta 1982).

O sítio, com 48 machas pretas, "cabanas", em formato elíptico, foi escavado a partir do quadriculamento $20 \times 20 \mathrm{~m}$, do subquadriculamento das áreas com concentração de material (cerâmica, lítico, ossos, chifres e fogueiras) e de decapagens em níveis naturais. Foram utilizados setores nomeados por letras e números, além de abertas trincheiras e perfis indicadores da sucessão dos diferentes níveis e da composição dos solos. O material arqueológico exumado foi encarado como "testemunho", "indispensável para a interpretação das atividades desenvolvidas pelo homem na aldeia pré-histórica" (Andreatta 1982), em clara alusão às abordagens de Pallestrini (1975: 114). Estes "testemunhos" foram analisados sem filiação a tradições: "cerâmica de tipo simples", "tipo decoração entalhada" e líticos ("peças modificadas pelo uso"), à luz das perspectivas de Tixier, Emperaire, Brézillon, Balfet, Meggers, Evans e Seronien-Vivien (Andreatta 1982). Paradoxalmente, Margarida é associada ao estudo da Tradição Aratu, mesmo sem o ter afirmado em relação aos sítios que estudou.

Interessante ressaltar que, neste momento, outros projetos são levados a cabo em Goiás, sob claro enfoque histórico do PRONAPA, 
como o Programa Arqueológico de Goiás, sob coordenação do Pe. Schmitz do Instituto Anchietano (Schmitz e Verardi 1995-1996) e o Projeto Integrado de Pesquisas Arqueológicas da Bacia do Paraná, sob coordenação de Alfredo Mendonça. Identificados com as posturas histórico-ecológicas pronapianas, arrolaram e determinaram uma série de fases e tradições, ao passo que Margarida seguia a "descrição completa de sítio, imitando mestres franceses”, como pontuou o Schmitz (Schmitz e Barbosa 1985).

Margarida abordou o sítio arqueológico Bonsucesso preocupada em evidenciar a forma, a dimensão e a organização espacial da aldeia, assim como a identificação de sua estrutura interna (Andreatta 1982). A visão de uma abordagem do "externo" (forma, espacialização) e do "interno" norteou as ações nos sítios históricos das Casas Bandeiristas em São Paulo, e a semelhança desta leitura com os aportes teórico-metodológicos da household archaeology permitiu a aproximação de seus orientandos com os autores processuais norte-americanos.

Em 1985, Margarida participa, como docente, do curso de Especialização "Antropologia: métodos e técnicas de Abordagem em Et-

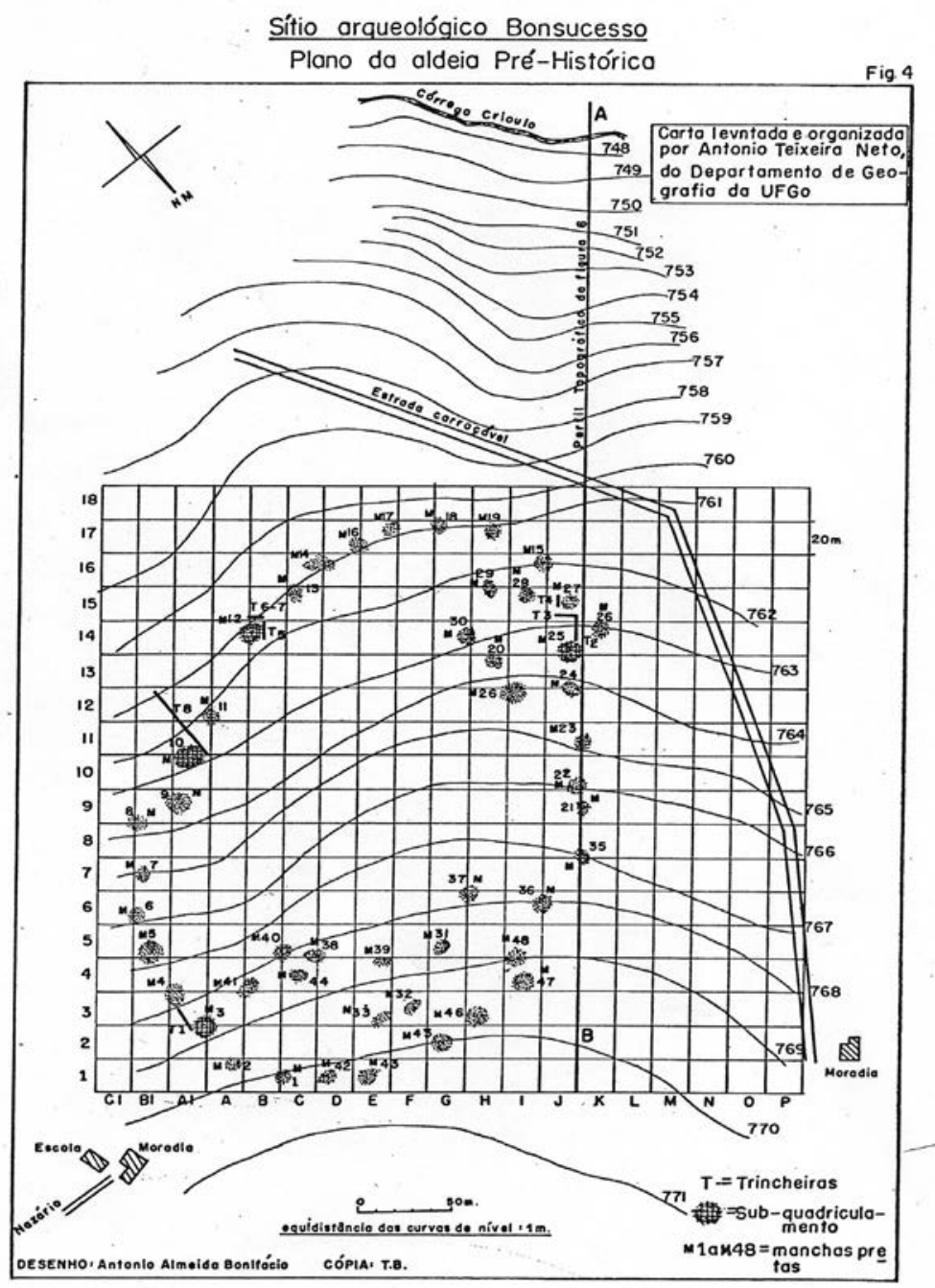

Figura 6: "Plano da aldeia pré-histórica" do sítio Bonsucesso (Andreatta 1982) 
nologia Regional", pela UFG, no qual orienta Dilamar Martins. Dilamar dá continuidade aos projetos em Goiás, já sob moldes preventivos, a partir do final dos anos 1990, com a participação de Margarida.

Em Goiás, a influência da metodologia de campo de Pallestrini (em especial quanto às "manchas de terra pretas") com o uso das superfícies amplas e das trincheiras para a leitura dos perfis estratigráficos (o método topográfico), métodos que Margarida já havia acompanhado com Leroi-Gourhan, são bastante evidentes. Por outro lado, a leitura do material lítico lascado é influenciada pelos estudos de Jacques Tixier.

Com isso, sua abordagem aos materiais lascados ordena as tipologias dentro do conceito de cadeia operatória. Esta corrente interpretativa francesa, com influências dos Emperaire, Tixier e outros, por vezes, afastou a arqueóloga das possibilidades de atuação no país, quando da hegemonia do PRONAPA, já que levava a pesquisadora a pensar em termos de tecnologias, cadeias operatórias e experimentação, em resposta a uma arqueologia pautada exclusivamente em culturas e tipologias arqueológicas (Reis 2007: 93).

As sugestões de Margarida (1968) em torno da nomenclatura de alguns artefatos líticos disseminaram-se; Kneip (1977) opta, por exemplo, pela terminologia "peça com depressão" em substituição a "quebra-coquinho" segundo "Andreatta 1968". No final dos anos 1970, a dedicação aos artefatos líticos ainda apresenta fôlego, com pesquisas no vale do Paranapanema, no vale do Itararé e no Paraná, antes da mudança quase que definitiva para as temáticas da Arqueologia Histórica. Participa, nos anos 1970, das pesquisas do Projeto Paranapanema, escavando os sítios Alves, Jango Luís, Almeida e Regadas Garcia (um sítio tupi-guarani escavado em 1979. Voltaria ao contexto com o diagnostico para o Sítio Santa Marina, em Jacareí, em 1988).

Em 1976, Margarida publica as análises de 415 artefatos líticos do sítio Alves, o primeiro sítio escavado em Piraju, no âmbito do Projeto Paranapanema, entre 1969 e 1971. Sob perspectivas similares foram analisados os líticos dos sítios Fonseca, Jango Luis e Almeida (Morais 1983), este, com componentes de "contato" associado aos jesuítas. O contexto do Almeida, somado a coordenação das prospecções nas ruínas do Abarebebê, em Peruíbe, com Dorath Uchoa, relacionado a uma missão jesuítica do século XVI, nos anos 1990, justificam a presença da professora em bancas e em orientações sobre o assunto (Thomaz 1996; Najjar 2005).

Soma-se a esta trajetória o fato de Margarida ter feito parte de um dos primeiros trabalhos com aporte etnoarqueológico realizados na América Latina (Politis 2003), ao analisar a indústria lítica dos Xetá, da Serra de Dourado, do Paraná, alvo, nos anos 1940, de agressivas políticas de expansão sobre seus territórios tradicionais. Esta atividade foi resultante do programa organizado por Loureiro Fernandes, que realizou expedições durante o período de 1955 a 1961. A análise da cultura material Xetá ficou a cargo de Annette Emperaire, Maria José Menezes e de Margarida, com artigos publicados entre 1964 e 1978 (Emperaire, Menezes e Andreatta 1979). A tecnologia lítica Xetá seria mais tarde estudada também por Tom Miller.

Enquanto isso, os anos 1970 foram, sem dúvida, de alguma efervescência e avanço para a Arqueologia Urbana em São Paulo. Marlene Suano, da USP, coordenou prospecções arqueológicas numa casa bandeirista no bairro do Jabaquara, o sítio da Ressaca, em 1978 (Zanettini 2005: 36). O sítio seria prospectado novamente por Andreatta em 1979. Pereira Jr, em 1973, realizou escavações arqueológicas no sítio da antiga Igreja do Pátio do Colégio, onde teria encontrado enterramentos (Juliani 1996). Nos anos 1940, Loureiro Fernandes realiza prospecções arqueológicas, a convite de Luis Saia, então diretor do SPHAN, para o tombamento do sítio Santo Antônio, em São Roque (Zanettini 2005). Estes exemplos marcam a ampliação das temáticas de pesquisa da arqueologia do território paulista que, do século XIX aos primeiros anos do século XX, esteve focada, mormente, nos sambaquis (Wichers 2012).

Com os anos 1980, um programa de cooperação, no âmbito das políticas de conservação e restauro, entre o DPH e o MP possibilita a sistematização de escavações de inúmeros sítios na cidade, sempre com foco nas chamadas Casas Bandeiristas, mas também em locais no centro 
(Andreatta 1981/1982). Percebe-se, entretanto, que quase quarenta anos decorreram para que a Arqueologia Urbana, e a Arqueologia Histórica, configurasse-se na cidade. Entre os anos 1940 e o final dos anos 1970 permaneceu em relativa hibernação, o que lhe rendeu atraso em relação a pesquisas realizadas em outros estados como Rio Grande do Sul, Paraná e Pernambuco (Zanettini 2005: 39).

No final dos anos 1970, a experiência com os contextos arqueológicos clássicos foi entendida como o link, no âmbito da Arqueologia Histórica, que tornou possível o convite, pelo DPH/SMCSP, a partir do MP/USP, para a criação do Programa de Arqueologia Histórica no Município de São Paulo. Seguindo as diretrizes da Carta de Veneza (1964), o DPH sentiu necessidade de implantar um serviço arqueológico como "subsídio de recuperação e restauração de bens históricos edificados” (Campos 1995-1996). Segundo Margarida, "as escavações em velhos casarões tinham por objetivo subsidiar o restauro. Buscávamos reconstituir o padrão construtivo, a cor das paredes, as telhas originais".

$\mathrm{O}$ programa esteve associado à Arquitetura, elucidando técnicas de construção, períodos de reformas (Andreatta 1986) e coletando informações que auxiliassem no restauro de edifícios. A isto Margarida chamaria "pontos arquitetônicos” evidenciados através da Arqueologia: indícios de fundação de taipa de pilão, esteios de madeira, soleiras, acessos, "locais de atividades familiar-sociais e de trabalho" (Andreatta 1981/1982). Por isso as escavações priorizariam a reconstituição de plantas baixas e a evidenciação de "solos-pisos" de ocupação, divisórias e vias de circulação interna.

Os edifícios eram escolhidos pelo "valor arquitetônico" representativo de um período da cidade de São Paulo; refletiam os nortes da política cultural dos últimos anos do regime militar de preservar os monumentos representativos como "testemunhos do gênio da raça" (Silva 2001). Além disso, eram encarados pela Arqueologia como "ilhas preservadas de solo não-perturbado" pela dinâmica urbana (Campos 1995-1996). O "edificado" faria parte das leituras de Margarida sobre sítios históricos, assim como da escolha dos tipos de sítios em que atuou.
Andreatta dá início, assim, como coordenadora, junto do então diretor do DPH, Murillo Marx (Araújo; Campos e Juliani 2005: 129), às pesquisas, pautadas em estudos sistemáticos, de prospecções e escavações em "Casas Bandeiristas" e em locais de "interesse histórico" do Município de São Paulo, como becos, ruas, quintais e praças, entre os anos de 1979 e 1981 (Zequini 2006: 35), com atividades, todavia mais esporádicas, até 1992 (Juliani 1996). Visariam "interpretar a ocupação espacial e tentar delinear as atividades desenvolvidas pelos habitantes das casas coloniais rurais" (Campos 1995/1996). O objetivo último do projeto seria montar um núcleo de Arqueologia Histórica para atuar em âmbito municipal (Zanettini 2005: 3).

De fato, está claro o pioneirismo do Programa de Arqueologia Histórica no Município de São Paulo (Lima 1993) no continente americano, estabelecendo parâmetros para interpretações das cerâmicas de fabrico local, dos itens importados, das evidências de forja, investigando padrões de assentamento, construções, descartes, distinguindo áreas de atividade em termos funcionais. Estas prerrogativas aproximavam-se do que vinha sendo discutido pela household archaeology americana. Uma vez que as casas são abordadas enquanto unidades sociais e econômicas de análise, nas quais estruturas e disposições no espaço são esclarecedoras, às vezes mais que os artefatos em si, da dinâmica da casa, Margarida entendia as transformações e histórias do sítio como passos fundamentais a sua compreensão (Beaudry 2002). Esta abordagem seria aprofundada por seu orientando Paulo Zanettini (2005).

Para Margarida, os "testemunhos arqueológicos" contribuiriam para a interpretação da ocupação do espaço e das atividades desenvolvidas por seus habitantes (Andreatta 1986). Os objetos eram encarados como reflexo de relações sociais, testemunhas da trajetória humana. A perspectiva do "objeto testemunha", fruto da Antropologia de finais do século XIX, prerrogava que "o objeto é dado ou documento capaz de fornecer pistas à compreensão das culturas afastadas no tempo e/ou espaço da cultura ocidental” (Leitão e Pinheiro-Machado 2010). $\mathrm{O}$ "testemunho arqueológico" seria um dado 
bruto para documentar, de maneira objetiva e concreta, tradições e costumes, associando-se ao evolucionismo cultural e à história evolutiva (Leitão e Pinheiro-Machado 2010).

De 1979 a 1981, Margarida realiza prospecções e resgates nos sítios arqueológicos Mirim, Morrinhos, Casa do Tatuapé, Casa no 1, Beco do Pinto e Casa do Grito. A metodologia executava trincheiras "para verificação da sucessão de camadas, a fim de estabelecer comparações entre diferentes níveis internos e externos", evidenciando os "solos-pisos de ocupação e testemunhos neles existentes, pela técnica de decapagem em níveis naturais, a fim de não ser alterada a posição do material encontrado, que permitirá a interpretação dos achados arqueológicos" (Andreatta 1981/1982). Alem das trincheiras, Margarida realizava cortes e cachimbos (entendidos como cortes menores, junto a estruturas, para verificar fundações [Anjos 1998]), evidenciando paredes, pisos, janelas originais e a relação entre cômodos.

$\mathrm{Na}$ Casa $\mathrm{n}^{\circ} 1$, foi aberta uma trincheira no quintal, com $2 \mathrm{~m} \times 8 \mathrm{~m} \times 2,5 \mathrm{~m}$, e realizados cortes estratigráficos que evidenciaram níveis horizontais; no Beco do Pinto, subdividido em setores de A a P, com quadriculamento de $2 \times 2 \mathrm{~m}$, foram feitos cortes para perfis estratigráficos e evidenciada a antiga calçada por uma trincheira (Chermann 2008). Na Casa do Grito foram abertas três trincheiras na parte externa, a 0,40m das paredes de pau-a-pique; além disto, "foram feitas em três dessas trincheiras um corte, e na trincheira 4, dois cortes, perpendiculares, chamados cachimbos, para verificação da sucessão das camadas até o solo original do local. Nas dependências interiores, foram também abertas seis trincheiras com a mesma finalidade que as do exterior" (Andreatta 1986). As trincheiras eram ampliadas para decapagem de acordo com as evidências nelas encontradas.

Neste ínterim, em 1982, Margarida é chamada para coordenar as escavações das ruínas das caieiras coloniais na Ilha do Casqueirinho, em Cubatão, onde foram localizados cinco sambaquis escavados por meio de parceria entre o IPH, o MP e a COSIPA, sob coordenação de Dorath Uchoa e Caio Garcia. O local referia-se a um forno de cal edificado, dos séculos XVII e XVIII, que utilizava os próprios sambaquis para

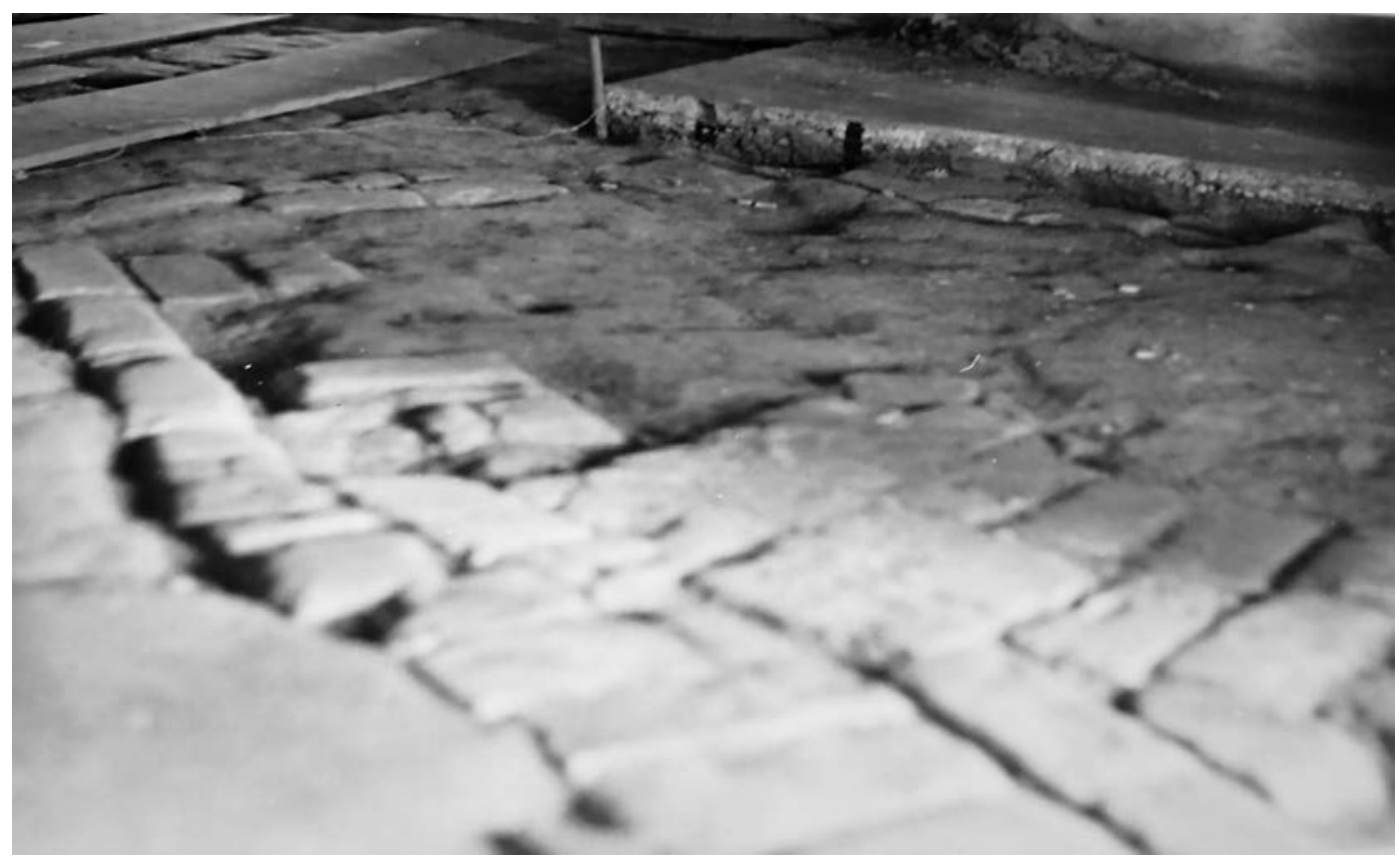

Fig. 7: Decapagem do piso nas escavações na Casa do Tatuapé (Acervo DPH) 
calcinação (Uchoa e Garcia 1986). Os resultados do trabalho foram apresentados na IV Reunião da $\mathrm{SAB}$, a primeira a "forçosamente" abrir espaço aos consideráveis trabalhos de Arqueologia Histórica do país (Uchoa e Andreatta 1987; Lima 1993).

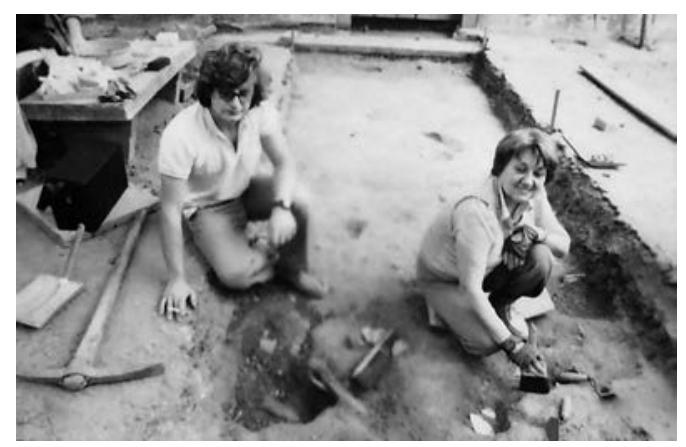

Fig. 8: Paulo Zanettini e Margarida Andreatta na Casa do Grito (Acervo DPH)

Apenas em 1983, ano em que a equipe do DPH escava o sobrado do sítio Florêncio de Abreu, residência do final do século XIX (escavada, depois, em 1992 por Astolfo Araújo e Marcos Carvalho [1999]), Margarida torna-se professora associada ao Museu de Arqueologia e Etnologia da USP (onde orientou, até 2012, 23 alunos), e, em 1984, ao Núcleo de Arqueologia da Universidade Brás Cubas, em Mogi das Cruzes. O sítio Florêncio de Abreu é um dos poucos sobrados do século XIX escavados na cidade, além do Solar da Marquesa.

A entrada no MAE é fruto do período de avanços no estatuto legal da instituição, com a consolidação de áreas de pesquisa, contratação de profissionais e conformação da pós-graduação em Arqueologia (Fleming e Florenzano 2011). No MAE, Margarida ministrou, entre 2001 e 2010, sua única disciplina, intitulada "Arqueologia Histórica - testemunhos históricos como documento arqueológico". Segundo a última ementa do curso, seu objetivo era “apresentar elementos e estudos da Arqueologia Histórica para reflexão a respeito das relações entre documentos textuais e materiais" segundo a justificativa do papel da Arqueologia para a construção de elos entre as comunidades presente e as do passado, surgidos "quando sua herança cultural (material e imaterial) é valorizada pela história, pela tradição escrita e oral e pelos vestígios coletados em pesquisas".

A ementa sintetiza muitas das ideias de Margarida ao longo de sua trajetória, como os métodos e técnicas da Arqueologia pré-histórica aplicadas a um novo contexto, as relações entre Arqueologia e Arquitetura (e os edifícios tombados) e a prerrogativa da cultura material enquanto "testemunho". Margarida dialoga, assim, com a perspectiva mundial que nos anos 1960-1970 tentava definir as teorias e, em especial, os métodos a serem utilizados nos "sítios históricos” (South, 1977; Schuyler, 1978).

Ao final do programa de São Paulo, ministra curso de Arqueologia Histórica no Museu Emilio Goeldi, no Pará, em 1986, contando com o sítio escola do Engenho Murutucu. As escavações realizam cinco cortes de $1 \mathrm{~m}^{2}$ e duas trincheiras (de 4,40m x 0,70m) para evidenciar um possível calçamento (Melo 2007). Antes, em 1982, havia vistoriado o acervo arquitetônico, em vias de desaparecimento, conhecido como "Chácara do Sossego”, em Sourre, na Ilha de Marajó, composto por prédios do início do século XX. Estas atividades dão início a Arqueologia Histórica na região Amazônica e ao estudo arqueológico dos engenhos coloniais situados no estuário amazônico, alguns anos mais tarde, em 1988, alvo das pesquisas de Anderson e Marques (Marques 2004).

Foi apenas 1986 que se deram as primeiras experiências de orientação de projetos de pesquisa de cunho acadêmico (fora aquela na especialização da UFG em 1985) aos moldes de iniciações científicas: uma na USP, sobre a tecnologia e ocupação humana na Fazenda Ipanema, e outra sobre o estudo da cerâmica do sítio arqueológico GO.RV.1 pela UFG. Seu primeiro aluno em nível de pós-graduação strictu senso, Lúcia Juliani, inicia a orientação para o mestrado somente em 1990, na USP, em torno, justamente, da gestão do patrimônio arqueológico urbano paulistano.

As pesquisas de Andreatta claramente renderam frutos em São Paulo. Alguns personagens podem ser mapeados, como seus alunos Lucia Juliani, Paulo Zanettini e Maryzilda Campos. A geóloga Lucia, o historiador Paulo e artista 


\section{PLANTA-A}

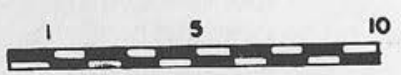

OESTE

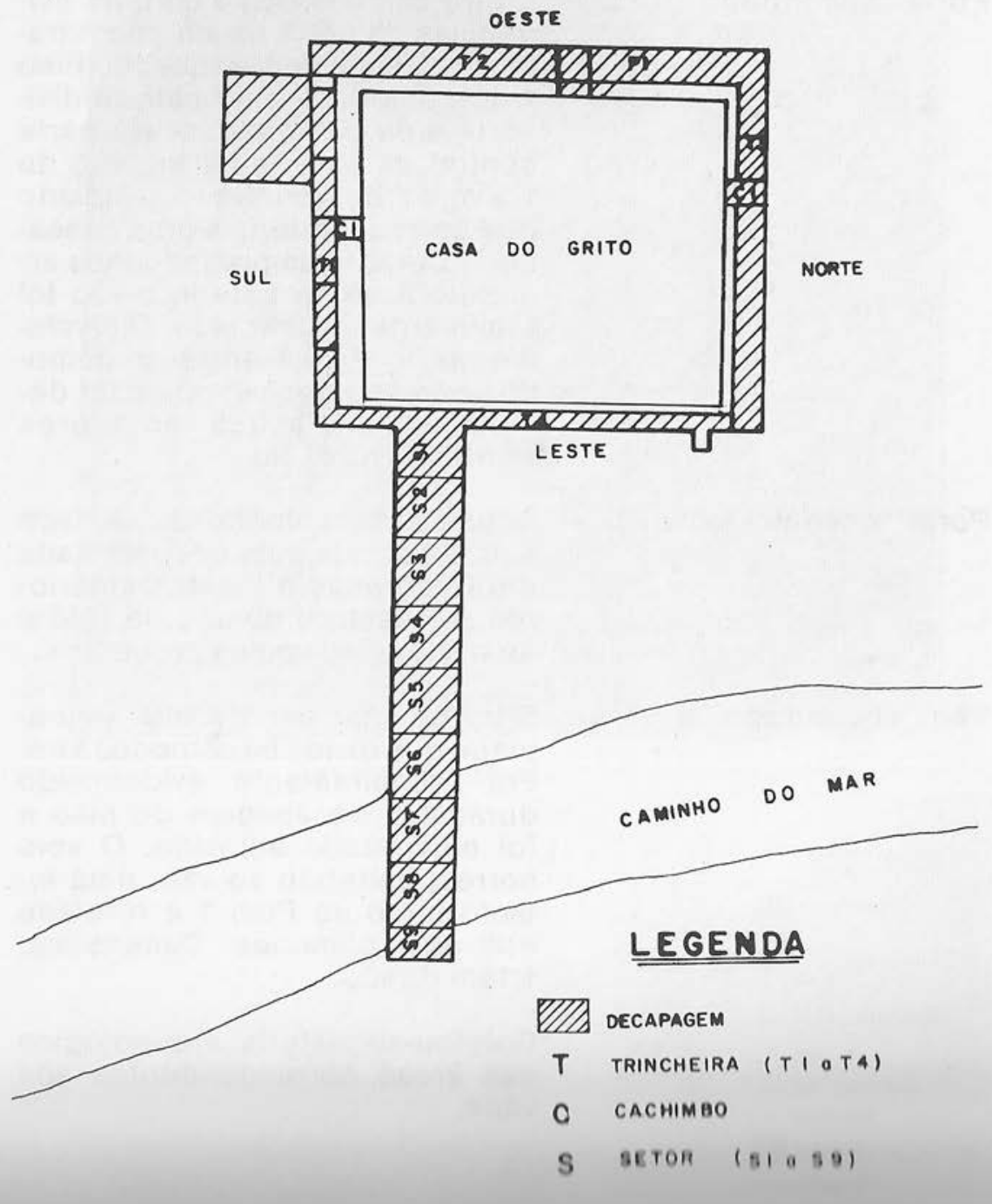

Fig. 9: Planta da escavação da Casa do Grito (Andreatta 1986) 
plástica Maryzilda atuariam como arqueólogos do DPH nos anos 1980 e 1990, na Seção de Arqueologia, dando andamento a algumas escavações na cidade, como a do Solar da Marquesa de Santos, sobrado de taipa de pilão do século XVIII, em 1985, sempre sob orientação da Prof. ${ }^{a}$ Margarida. Nele realizaram trincheiras e cortes para perfis estratigráficos, além das decapagens em níveis naturais (Campos 1995-1996).

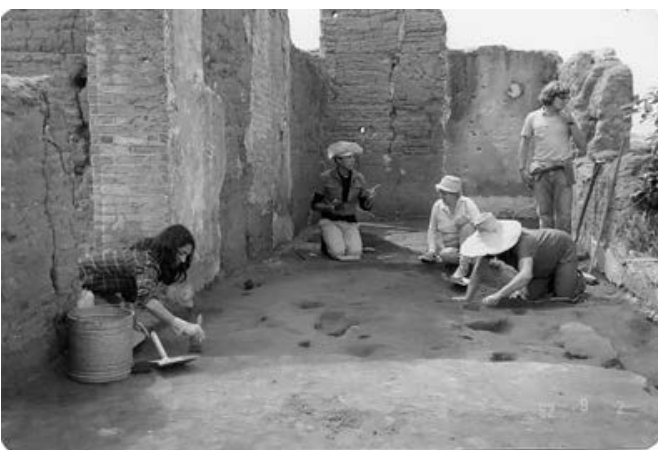

Fig.10: Escavações do sítio Mirim em 1982. Participam Lucia Juliani, à esquerda, e Paulo Zanettini, em pé (Acervo DPH)

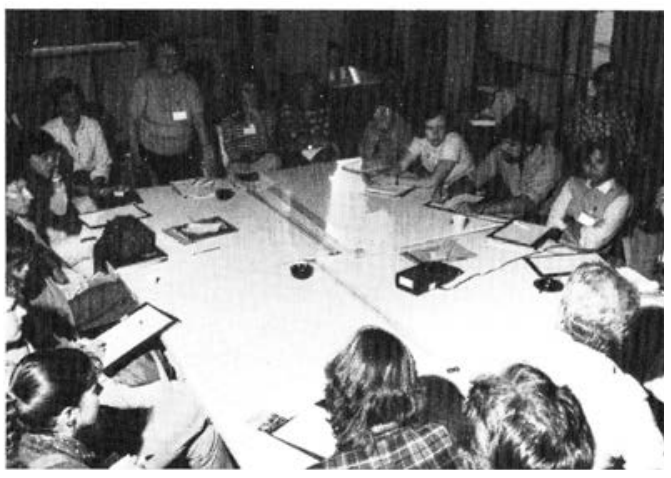

Fig. 11: 1o Seminário do Patrimônio Histórico da Cidade de São Paulo

Os anos 1980, e pelo menos até meados dos 1990, assistem a uma efervescência no mundo da Arqueologia Histórica e nas tentativas de romper isolamentos e indiferenças do restante da comunidade arqueológica do país (Zanettini e Cazzetta 1993). Em 1985, acontece o 1 Seminário do Patrimônio Histórico da Cidade de São Paulo, uma das primeiras iniciativas do tipo, com mesa intitulada "Arqueologia Histórica", da qual participam, além de Margarida, Arno Kern, Ulysses Pernambucano e Cristina Sá. Presentes estavam os arqueólogos do DPH, Paulo, Lúcia e Maryzilda, a informar sobre as escavações na Casa no 3, o Solar da Marquesa. No mesmo ano ocorreu, no Rio, o 1º Seminário de Arqueologia Histórica, que reuniu a maioria dos arqueólogos envolvidos com o tema (Lima 1993).

Entre 1988 e 1989, Margarida escava, junto de Dorath Uchoa, um dos sítios mais emblemáticos da cidade, a Casa Bandeirista do Itaim Bibi, casa de taipa de pilão do século XVIII, arrolada por Mário de Andrade como uma das "casas velhas" que constam do primeiro relatório enviado a Rodrigo Melo Franco, em 1937. A Casa é uma das últimas somadas à lista de edificações do "padrão bandeirista" da região, juntamente ao sítio do Capão (escavado anos mais tarde por Paulo Zanettini, em 2003). Nela foram efetivadas intervenções na casa-sede e no anexo de taipa, limpeza do entulho do interior da casa e abertas quatro trincheiras, 59 "cachimbos" e realizadas decapagens.

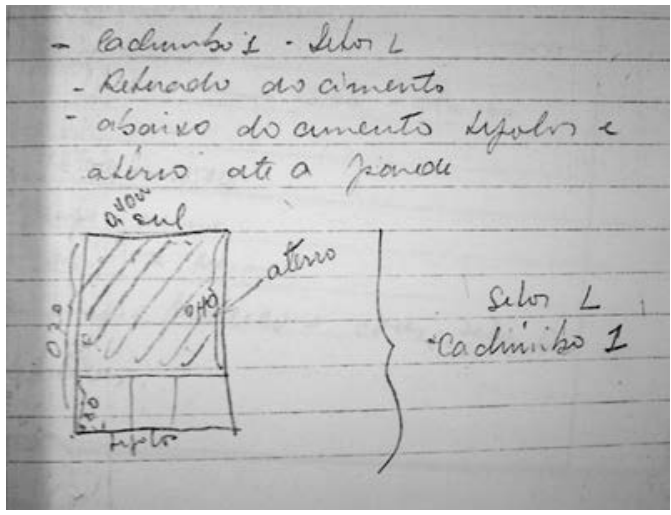

Fig. 12: Croqui de cachimbo realizado no Beco do Pinto (Acervo DPH)

Anos mais tarde, em 2009, o sítio arqueológico e bem tombado foi parcialmente destruído, na "calada da noite", durante as obras de um dos empreendimentos imobiliários mais caros da história da América Latina. O Termo de Ajustamento Judicial e o Termo de Ajustamento de Conduta decorrente giraram em torno das pesquisas realizadas por Paulo Zanettini e equipe, com Margarida como consultora. Ironica- 
mente, a multa do TAC foi destinada a construção do novo prédio do MAE/USP, a mesma instituição na qual a Arqueologia Histórica não é, e nunca foi, muito prezada.

A partir do final dos anos 1980 e ao longo da década de 1990, Margarida, ainda escavando sítios com ruínas ou edificações, engloba a seus trabalhos a Arqueologia Industrial, área que engatinhava na cidade, realizada em terrenos tombados. Entre 1983 e 1989 dá andamento às pesquisas no sítio arqueológico Afonso Sardinha, em Iperó, relacionado à fabricação de ferro no morro de Araçoiaba entre os séculos XVI e XVIII e à Real Fábrica de Ferro de Ipanema, mais tarde alvo do estudo de sua aluna de doutorado Anicleide Zequini (2002-2006), do Museu Republicano de Itú. Junto das escavações no Engenho dos Erasmos, é exemplo da influência da Carta de Veneza na configuração do Patrimônio Industrial do estado que, a partir do final dos anos 1970, e, sobretudo, com os anos 1980, começa a ganhar nova roupagem (Rodrigues 2010).

Em 1988 e 1990, Margarida leva a cabo as primeiras intervenções arqueológicas associadas a uma Operação Urbana (pela EMURB), acom- panhando as obras no Vale do Anhangabaú. Localizou o antigo córrego e as obras do fim do século XIX, bolsões de lixo, trilhos de bonde, traçados de antigas ruas e as fundações do antigo Viaduto do Chá, a partir de obras abertas pelo empreendedor (Juliani 1996). As pesquisas tinham como objetivo registrar as evidências expostas pela obra e compreender a evolução urbana da cidade (Juliani e Campos, 1988). O programa enfrentou inúmeros desafios, como o fato da primeira etapa permitir o acesso de dois técnicos, acompanhados, por apenas uma hora aos canteiros de obra (Juliani e Campos 1990).

Esta foi a primeira tentativa de desenvolvimento de uma metodologia de Arqueologia Urbana em São Paulo, indicando a potencialidade e alta densidade de vestígios no solo urbano e a necessidade inerente de critérios para uma gestão arqueológica das obras de infraestrutura na cidade (Juliani 1996; Juliani et al 1988). A experiência conduziu a elaboração e inclusão de dispositivo de proteção ao patrimônio arqueológico na cidade de São Paulo na nova Lei Orgânica do Município de 1990, pelo Artigo 197 (Zanettini e Cazzetta 1993).

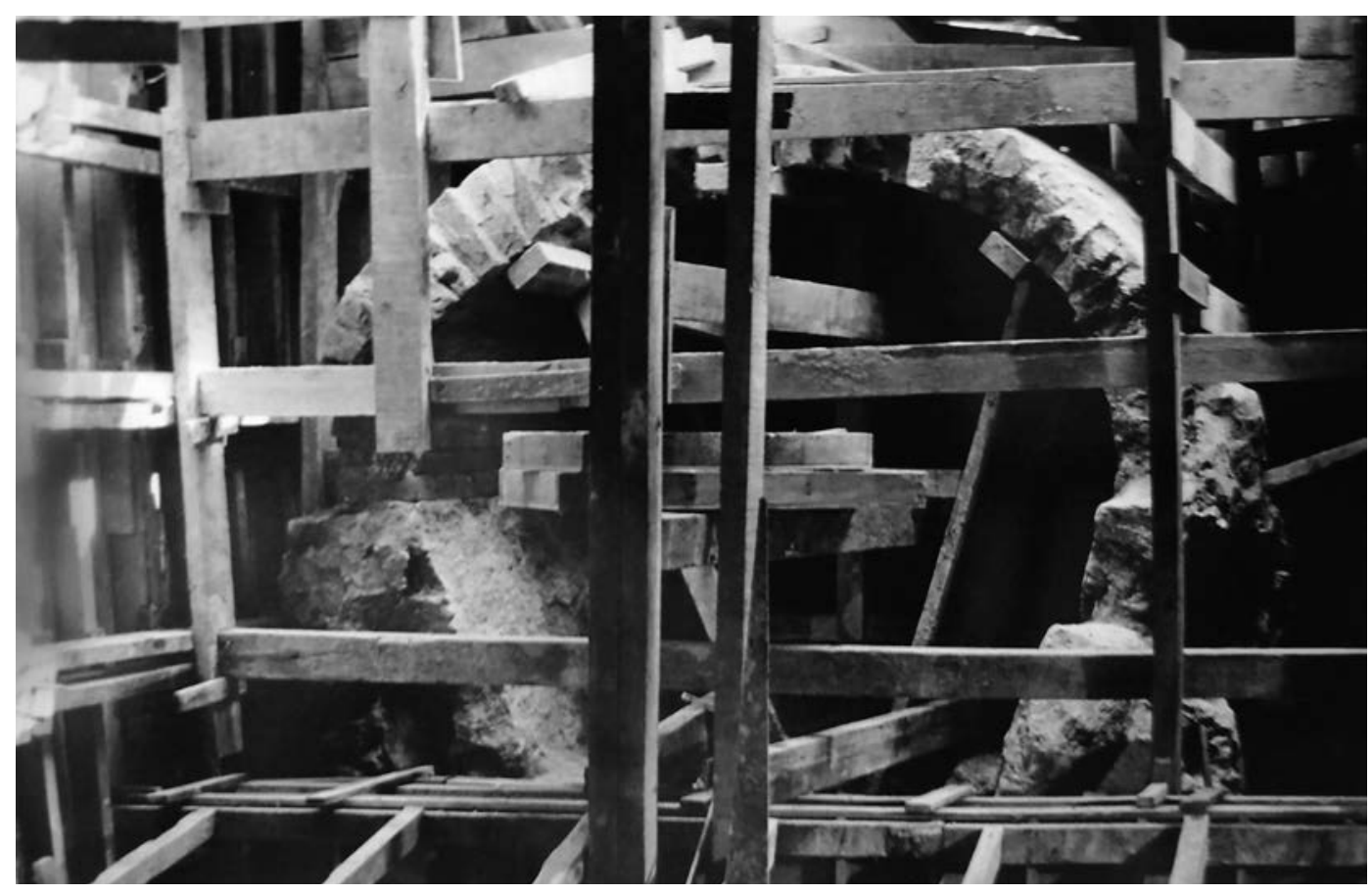

Fig. 13: Obra de canalização do ribeirão do Anhangabaú (século XIX) (Acervo DPH) 
Em 1989, Margarida vistoria a vila operária de Paranapiacaba, construída pela São Paulo Railway Company em 1867, mais tarde alvo do mestrado de sua orientanda Cláudia Plens (2002). Em 1990, prospecta a Calçada do Lorena, durante sua restauração, em trecho correspondente à descida da Serra do Mar, construído em 1792 para facilitar a fiscalização dos metais e pedras preciosas provenientes do interior do Brasil; o tema foi alvo do mestrado de Paulo Zanettini entre 1993 e 1998.

Em 1991, convênio da Prefeitura Municipal de São Caetano do Sul e de seu Museu Histórico com o MP/USP dá início a pesquisas em Arqueologia Histórica a partir das sugestões de Sonia Xavier, supervisora do MHSC, e de José de Souza Martins, da FFLCH/USP a Ulpiano Meneses, então diretor do MP, que designa Margarida para coordenar as escavações, acompanhada dos estagiários Willer Bonni, Cecília Correia, Leandro Duran, Hildo Maesima e Silva Melchior (Maesima 1997).

As pesquisas no sítio Bairro da Fundação deram-se na face sul da antiga Igreja Matriz, na praça Ermelino Matarazzo, a partir de "métodos de decapagem em ampla superfície com a execução de trincheiras, cortes, e perfis estratigráficos, como indicador das diferentes camadas e composição do solo" (Maesima 1997). O sítio foi dividido em setores, nomeados por letras do alfabeto, a cada $2 \mathrm{~m}$. Durante esta etapa foram prospectadas as Indústrias Reunidas Fábricas Matarazzo São Caetano, complexo industrial ativo entre os anos 1910 e os anos 1970. As escavações foram abandonadas devido à contaminação do terreno por inúmeros produtos químicos, não sem antes resultar na dissertação de mestrado de Henry Maesima sobre os tijolos encontrados.

Entre 1995 e 1997, Margarida escava o próprio MP a partir de intervenções visando a abertura de novas áreas no subsolo, que localizaram camadas de entulhos de materiais utilizados durante a construção do edifício (1885-1895) e objetos trazidos pelos operários que ali trabalharam, como esquadros, caixa de fósforos, garrafas de cerveja e resíduos alimentares. Segundo a arqueóloga, o "material encontrado no subsolo trouxe subsídios importantes para a história dos costumes, da arquitetura, da engenharia e também ampliou o conhecimen-

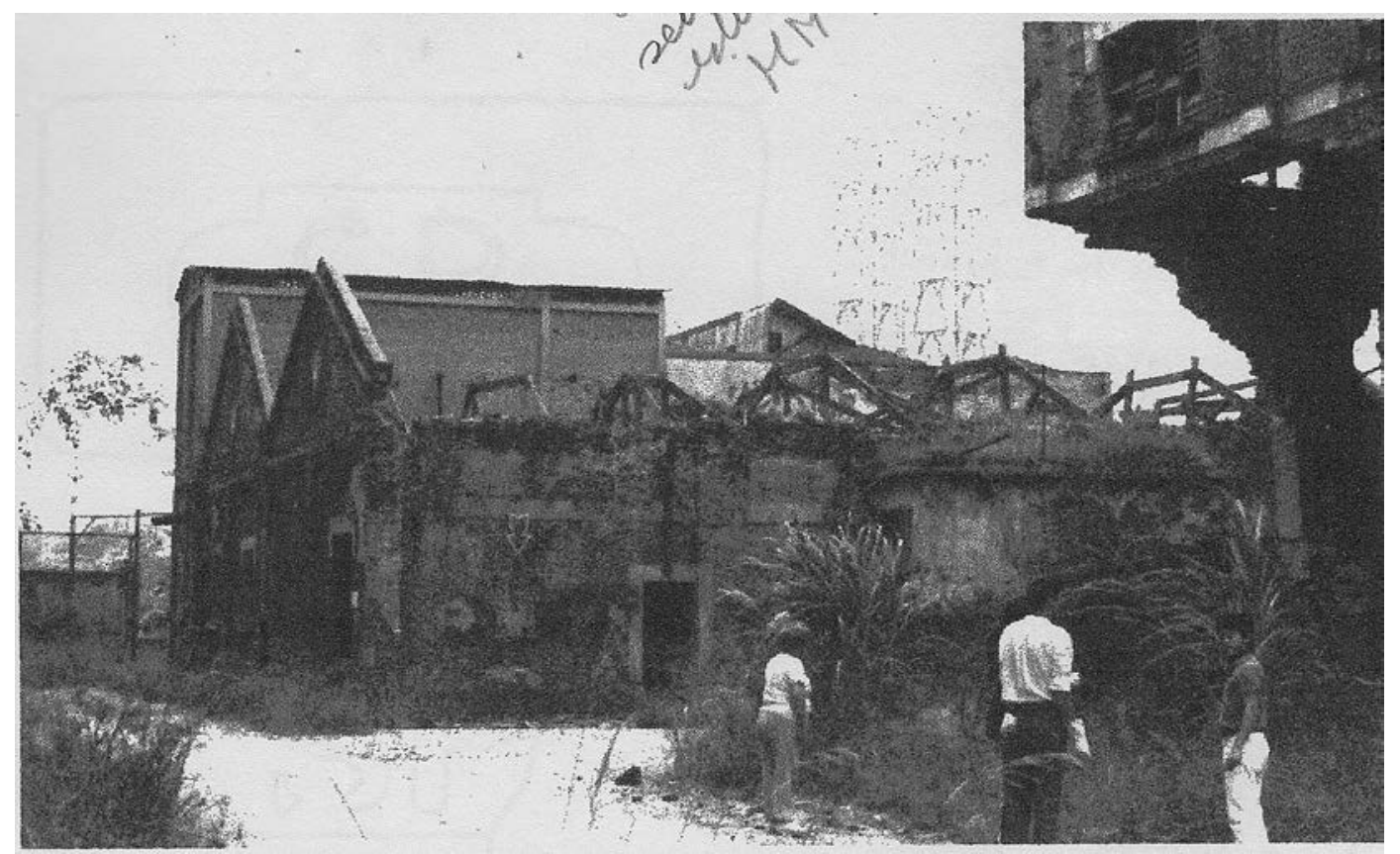

Figura 14: Prospecções nas IRFM São Caetano (Maesima 1997) 
to sobre o processo construtivo na virada do século" (Jornal USP, 1998).

Em 1995, coordenadora do NAUBC a cerca de 12 anos, inicia as pesquisas em Mogi das Cruzes com o Projeto de Arqueologia da Região da Serra do Itapety, que localiza cerca de 15 sítios, com escavações em superfície ampla e etnográficas, "ataques horizontais" e leituras estratigráficas realizadas por trincheiras de $1,10 \mathrm{~m}$ x $2 \mathrm{~m} \times 1 \mathrm{~m}$; foram utilizados setores, organizados a cada $10 \mathrm{~m}$, nomeados por letras do alfabeto (Tomiyama 2002). Junto de Vivan Fernandes, Nair Tomiyama e Davi Chermann, seus orientandos no MAE/USP, escava outros sítios do vale do Paraíba, sempre com metodologias e perguntas semelhantes. Com o projeto retoma a temática industrial com o sítio Lago do Parque, em Mogi, relacionado ao serviço de captação de água no XIX.

Entre 1997-1999, através de termo de cooperação técnica e administrativa da USP com a Prefeitura de Santos, Margarida coordena escavações no Engenho dos Erasmos, das quais participa a arqueóloga Eliete Pythágoras. A escavação possibilitaria a evidenciação do material arqueológico, através de ataque horizontal, enfatizando a representatividade dos "referencias socioespaciais do passado" (Andreatta 1999). Margarida buscava, assim como nas Casas Bandeiristas, auxiliar no entendimento do modelo construtivo do engenho, subsidiando trabalhos para a revitalização do conjunto, e delinear as linhas essenciais de suas condições socioeconômicas.

O sítio também foi dividido em setores identificados por letras do alfabeto, cuja metodologia abarcou cortes de verificação, sondagens para delimitação dos limites e trincheiras "para evidenciar estruturas e diferentes horizontes de solo" (Andreatta 1999; Anjos 1998). As escavações foram feitas a partir do quadriculamento dos setores e aplicação do método de superfie ampla para compreender locais de residência, capela e estabelecer a circulação interna do açúcar, identificando as atividades econômicas e sociais do engenho (Andreatta 1999). Os "testemunhos arqueológicos", classificados como "cerâmica", "louça branca", "porcela- na" e "faiança" (sob as prerrogativas de Tânia Andrade Lima para as faianças finas). $\mathrm{O}$ uso destas categorias artefatuais estaria presente no trabalho de diversos de seus orientandos, assim como a ausência ou parcimônia na utilização de "cerâmica neobrasileira" delineada por Ondemar Dias.

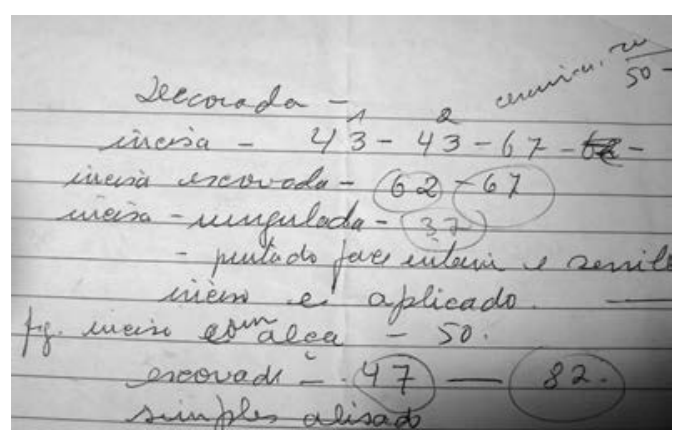

Fig. 15: Análise da cerâmica do sitio Casa do Itaim: "decorada incisa, incisa escovada, incisa-ungulada" (Acervo do DPH)

O uso destas categorias, associada à metodologia e técnicas que a própria Margarida utilizou a partir da Arqueologia Pré-Histórica, como ela mesma afirma em diversos momentos (Andreatta 1981/1982; 1999), marcou a formação de muitos pesquisadores, seja pela não utilização de categorias da "tradição neobrasileira" seja pelo uso de metodologias específicas. Poucos de seus alunos utilizam o termo, sempre com ressalvas.

O trabalho com fábricas e em contextos associados ao século XX indica, igualmente, uma postura bastante aberta em relação ao significado da cultura material, que possibilitou minha própria orientação sobre um sítio industrial, o cotidiano operário e a produção de faiança fina brasileira na primeira metade do século XX (Souza 2010). Para Andreatta, em postura rara, o século XX é passível de leitura arqueológica.

Em 1999, realiza prospecções no sítio Lavras de Afonso Sardinha, no Pico do Jaraguá, expoente das primeiras minerações portuguesas na América do século XVI. Mais tarde, junto de Paulo Zanettini e Érika Gonzalez, entre 2001 e 2003, pelo projeto do Rodoanel, volta às cavas de ouro coloniais. 
Com os últimos anos da década de 1990 e a entrada no século XXI, Margarida é consultada para a realização de vistorias em sítios históricos da Grande São Paulo, em geral casas de taipa de pilão dos séculos XVII e XVIII, engenhos, igrejas etc. Escava sítios pontuais no estado, como o Jardim Quatro Estações, em 2008, casarão do século XIX que sedia o Museu Republicano de Itú, com Angela Ribeiro e Anicleide Zequini.

Entre 2002 e 2006, compôs o Grupo de Estudos de Faianças e Porcelanas, com objetivo de obter conhecimentos técnico-produtivos e de usos sociais das louças, coordenado por Heloísa Barbuy do Museu Paulista. Disto, resulta a vistoria de Margarida à Fábrica Chiarotti, à Porcelana Kojima e à Cerâmica Teixeira em 2002.

É assim que as experiências de Margarida conformam campo com intelectuais que pensam a Arqueologia Histórica na cidade de São Paulo de maneiras específicas, longe das categorias ecológicas que marcam o conceito de tradição, utilizando métodos e técnicas de campo que foram (re)construídos de modo muito próprio aqui.

Com atuação bastante intensa na Arqueologia Urbana paulistana, Paulo Zanettini, por exemplo, levou a cabo estudos em torno do cotidiano dos paulistas entre os séculos XVI e XVIII a partir dos trabalhos de Margarida, com a qual se iniciou estagiário a partir da escavação da casa do Tatuapé, em 1979. É ele, já no final dos anos 1980 e ao longo dos anos 1990, quem dá continuidade ao uso de técnicas alternativas às escavações francesas na cidade, com a utilização de maquinário pesado e da amostragem para os sítios urbanos. Margarida foi uma das primeiras a utilizar maquinário em escavações urbanas, lançando mão da britadeira para romper as primeiras camadas arqueológicas formadas por cimento, asfalto e concreto, típicas superfícies impermeáveis da cidade. Chocou pesquisadores da época como Luciana Pallestrini. Zanettini utilizou o maquinário, por outro lado, para abrir trincheiras.

Os trabalhos de Margarida permitiram interessante interação da Arqueologia com o Restauro, pioneira no país no escopo da Arqueologia de Restauração (Zanettini e Cazzetta 1993; Najjar e Duarte 2002). Somam-se a isto suas experiências em Arqueologia da Mineração, Portuária (portos e armações de baleia), Industrial, dos Engenhos Coloniais, do cotidiano de unidades domésticas e em uma gama enorme de variações que possibilitaria a malacóloga de formação, Margarida, uma trajetória densa que pouco existe atualmente na Arqueologia.

Enveredando-se pelos caminhos e descaminhos da Arqueologia Histórica e Urbana na cidade de São Paulo, Margarida abriu e estruturou uma área desvalorizada, possibilitando a uma série de pesquisadores continuar e desenvolver caminhos próprios sobre as temáticas sem fim da Arqueologia Histórica, tecendo uma rede composta por intelectuais que, apesar de seguirem diferentes temáticas e possuírem especificidades, dispuseram de um arcabouço teórico-metodológico aprendido com Margarida.

Recentemente, Margarida foi homenageada em diversos momentos: em 2007, com o Prêmio Bunge; em 2009, pela SAB Sudeste por sua trajetória profissional; em 2011, pelos trabalhos prestados à USP e novamente por sua trajetória profissional pela SAB Nacional em Florianópolis. Desde 2011 Margarida faz parte do projeto Fala Escrita, com objetivo que construir a memória do Museu Paulista em linguagem audiovisual, contextualizando as documentações produzidas sobre os sítios escavados ao longo de sua vida acadêmica. 
SOUZA, R.A. Margarida Andreatta and the conformation of São Paulo Historical Archaeology. R. Museu Arq. Etn., São Paulo, n. 22: 157-180, 2012.

\begin{abstract}
This paper aims to highlight the role of Professor Margarida Davina Andreatta in the strengthening of the Historical (and Urban) Archaeology at São Paulo city through an understanding of her intellectual trajectory and the field to which she belonged. Margarida has participated at the formation of a whole group of archaeologists who worked in São Paulo with perspectives, although following different lines, having common ties, as, for example, the non utilization of the "Neo-brazilian" ceramic tradition terminology and the choice of specific field work methods.
\end{abstract}

Keywords: Margarida Andreatta, Historical Archaeology, São Paulo

\title{
Referências bibliográficas
}

\section{AMERICAN ANTIQUITY}

1975 Current Research. American Antiquity, v. 40, n. 2: 238-246

\section{ALBUQUERQUE, M.}

1986 Contribuição à técnica do recolhimento de esqueletos em Arqueologia. Clio - Série Arqueológica 3, Recife, n. 8: 177-181.

1992 Perspectiva da Arqueologia Histórica no Brasil. Anais da Reunião Científica da SAB, Rio de Janeiro: SAB/CNPq, 1992. v. 2: 508-515

ALMEIDA, F. E FERREIRA, O. V.

1966 A estratigrafia observada no local do "Balineum" lusitano-romano da Egitânia, Revista Guimarães, 76 (1-2): 109-116

ANDREATTA, M. D.

1960 Fauna Malacológica do Sambaqui do Machado. O Sambaqui do Macedo A 52 8, Paraná, v. 2: 92-93

1968 Notas sobre pesquisas realizadas no Planalto e Litoral do estado do Paraná. II Simpósio de Arqueologia da Área do Prata, São Leopoldo

1974 Escavações no sitio Lapa Vermelha IV. Anais do II Encontro inter-regional de Cientistas Sociais do Brasil, Garanhuns, Pernambuco

1976 O Sítio Alves e o estudo de sua indústria lítica no desenvolvimento do Projeto Paranapanema. Anais do XVII Congresso Internacional de Americanistas, Paris
1977 Sugestões para uma terminologia do material arqueológico de dente, chifre e osso. II Simpósio de Arqueologia da Área do Prato e Adjacências, São Leopoldo.

1981-1982 Arqueologia Histórica no Município de São Paulo. Revista do Museu Paulista, v. XXVIII: 174-176

1982 Padrões de povoamento em Pré-História Goiânia: Análise de Sítio tipo. Tese (doutorado), FFLCH/USP, São Paulo

1985 Projeto Anhanguera de Arqueologia, estado de Goiás (1975-1985). III Reunião Cientifica da SAB, Goiânia

1986 Casa do Grito - Ipiranga, Programa de Arqueologia Histórica no município de São Paulo. Revista do Arquivo Municipal, São Paulo.

1999 Engenho São Jorge dos Erasmos: Prospecção Arqueológica Histórica Industrial. Revista da Universidade de São Paulo, São Paulo, v. 41: 28-47.

2005 Loureiro, o Mestre. Arqueologia: Revista do Cepa, Curitiba, v. 3: 69-70

ANDREATTA, M. D. E MENEZES, M. J.

1968 Nota prévia sobre o Sambaqui B do Guaraguaçu. Revista do Cepa, Curitiba, v. 1: $10-22$

1975 Resultados parciais das pesquisas no sambaqui B do Guaraguaçu. Revista do Museu Paulista, São Paulo, v. XXII. 
ANDREATTA, M. D. E UCHOA, D. P.

1987 Caieira do Brasil Colonial: remanescentes na Ilha do Casqueirinho, Cubatão - SP. Anais IV Reunião Científica da SAB, 1987, Santos

ANDREATTA, M. D. E ZEQUINI, A.

2009 Sítios Arqueológicos Históricos: Jardim Quatro Estações, Itu - SP. Resumos do XV Congresso da Sociedade de Arqueologia Brasileira, Belém, 2009: 87

ANJOS, F. M. F.

1998 Engenho São Jorge dos Erasmos. Uma abordagem interdisciplinar do documento na Arqueologia Histórica. Dissertação (mestrado), FFLCH/USP, São Paulo

ARAÚJO, A. G. M. E CARVALHO, M. R. R.

1993 A louça inglesa do século XIX: considerações sobre a terminologia e metodologia utilizadas no sítio Florêncio de Abreu, São Paulo. Revista do Museu de Arqueologia e Etnologia, São Paulo, 3: 81-95

ARAUJO, A. G. M.; CAMPOS, M. C. E JULIANI, L.

2006 O Departamento do Patrimônio Histórico e a arqueologia no Município de São Paulo: 1979-2005. Revista do Arquivo Municipal, v. 204:129-138

AUGÉ, M.

1994 Não-lugar: Introdução a uma antropologia da supermodernidade. São Paulo: Papirus.

BECK, A.; ARAUJO, E. M.; DUARTE, G.M.; REIS, M. J, E ANDREATTA, M. D.

1971 Projeto Integrado de Pesquisa - O povoamento pré-histórico de Santa Catarina. Anais do Museu de Antropologia, UFSC, 4: $89-101$

BARRETO, C.

1999 A construção de um passado pré-colonial: Uma breve história da arqueologia no Brasil. Revista USP, 44: 32-51.

BEAUDRY, M. C.

2002 Household archaeology. ORSER, C. (org.) Encyclopedia of Historical Archaeology. Londres e Nova York: Routledge: 307-310

BOURDIEU, P.

2001 Os três estados do capital cultural. In: NOGUEIRA, M. A.; CATANI, A. (orgs.) Escritos de Educação, 3a ed., Petrópolis: Vozes, 2001: 73-79.

CAMPOS, M. C.

1995-1996 Arqueologia Histórica: Casa da Marquesa de Santos. Anais da VIII Reunião Cientifica da SAB, PUCRS, n. 1, v. 2: 409-416
CAMPOS, N.

2010 O papel do clero e do laicato católico no processo de constituição da Universidade Católica do Paraná (1959). Cadernos de Historia da Educação, v. 9, n. 1: 187-205

2011 Faculdade católica de Curitiba: insígnia do ensino superior católico paranaense (1950). Contrapontos, v. 11, n. 1: 53-61

CARVALHO, M. R. R.

1999 Pratos, xícaras e tigelas: um estudo de Arqueologia Histórica em São Paulo, séculos XVIII e XIX. Mestrado (dissertação), MAE/USP

CARVALHO, S. M. B.

2010 A formação do professor de Historia na Faculdade de Filosofia da Universidade Estadual de Ponta Grossa de 1950 a 1970. Tese (doutorado), UFPR

CHERMANN, D.

2008 Memória do futuro: registros arqueológicos em tempo real. Tese (doutorado), MAE/USP, São Paulo

CHMYZ, I.

2006 Acompanhando a associação brasileira de Antropologia por três décadas. ECKERT, C. e GODOI, E. P. (org.) Homenagens - Associação Brasileira de Antropologia 50 ANOS. Florianópolis: Nova Letra.

COMERLATO, F.

2003 Retrospectiva da Arqueologia Histórica em Santa Catarina. V Congresso Internacional de Estudos Ibero-Americanos, Porto Alegre.

DEPARTAMENTO DE PATRIMONIO HISTORICO

1985 Boletim do Departamento de Patrimônio Histórico, 2. São Paulo: DPH

EMPERAIRE, A. L. ET AL.

1974 Grottes et abris de la région de Lagoa Santa, Minas Gerais, Brésil : premier rapport de la Mission archéologique franco-brésilienne de Lagoa Santa / / par A. Laming-Emperaire ... [et al.] ; appendice de J. L. Leme; avec la collaboration de M. Andreatta. Mission archéologique franco-brésilienne de Lagoa Santa, 1971-1973. Cahiers d'archéologie d'Amérique du Sud, 1, Paris

EMPERAIRE, A. L. E ANDREATTA, M. D.

1976 Les Sambaqui de l'Ilha das Rosas dans la baie d'Antonina (Paraná). Cahier d'archaeolgie d'Amerique du Sud, Paris

EMPERAIRE, A. L.; ANDREATTA, M. D. E MENEZES, M. J.

1978 O trabalho da pedra entre os Xetá da serra dos Dourados, Estado do Paraná. Coleção Museu Paulista Série Ensaios, São Paulo, v. 2 
FLEMING, M. I. D. A. E FLORENZANO, M. B. B.

2011 Trajetória e perspectivas do Museu de Arqueologia e Etnologia da USP (19642011). Estudos Avançados (USP), v. 25, n. 73: $217-228$

FUNARI, P. P. A.

1997 Archaeology, History and Historical Archaeology in South America. International Journal of Historical Archaeology, 1, 3: 189-206

GUIMARÃES, M. S. B.

2003 Do lixo ao luxo: as premissas teórico-metodológicas e a noção de sambaqui. Boletim do Museu Nacional, Antropologia, n. 63: 1-23

GUIDON, N. E ANDREATTA, M. D.

1980 O Sítio Arqueológico Toca do Sítio do Meio, Estado do Piauí. Clio - Série Arqueológica, v. IV

HENRI-MARTIN, G.

1965 La Quina. Bulletin de l'Association française pour l'étude du Quaternaire, v. 3-4

JOHNSON, M. H.

1999 Rethinking historical archaeology. In: FUNARI, P. P. A.; HALL, M. e JONES,

S. (org.) Historical archaeology: back from the edge. Londres: Routledge: 23-36

JULIANI, L.

1996 Gestão arqueológica em metrópoles: uma proposta para São Paulo. Dissertação (mestrado)

KNEIP, L. - Universidade de São Paulo

1977 Pescadores e coletores pré-históricos do litoral de Cabo Frio, RJ. Fundo de Pesquisas do Museu Paulista da Universidade de São Paulo.

LEITÃO, D. K. E PINHEIRO-MACHADO, R.

2010 Tratar as coisas como fatos sociais: metamorfoses nos estudos sobre cultura material. Mediações, Londrina, v. 15, n. 2 : 213-247

LEROI-GOURHAN, A.

1961 Les fuilles d'Arcy-sur-Cure (Yonne). Gallia préhistoire, tome 4: 3-16

LIMA, T. A.

1993 Arqueologia Histórica no Brasil: balanço bibliográfico (1960-1991). Anais do Museu Paulista, vol.1, n.1: 225-262.

1995 Arqueologia Histórica no Brasil: uma experiência de ensino. Historical Archaeology of South America: 1-17

1999-2000 Em busca dos frutos do mar: os pescadores-coletores do litoral centro-sul do Brasil. Revista USP, São Paulo: 270-327
INSTITUTO ANCHIETANO DE PESQUISAS

2012 Encontro em São Leopoldo, 1968. Pedro Ignácio Shmitz, Guilherme Naue, Danilo Lazartotot, Pe. Rohr e Margarida D. Andreatta. Arquivo Pe. Schmitz. Disponível em http://www.anchietano.unisinos.br. Acesso: 14 abr 2012

MAESIMA, $\mathrm{H}$.

1997 Tijolos do sítio bairro da Fundação São Caetano do Sul: análise e identificação. Dissertação (mestrado), FFLCH/USP, São Paulo

MAIA, J. M. E.

2011 Ao sul da teoria: a atualidade teórica do pensamento social brasileiro. Sociedade e Estado, v. 26, n. 2: 71-94

MARANHÃO, M. F. C.

2006 Contextualizando imagens paranistas (1940. 1950): o filme etnográfico de Vladmir Kozak e as ciências sociais no Paraná. Curitiba: Faculdade Pe. João Bagozzi

MARQUES, F. L. T.

2004 Um Modelo da Agroindústria Canavieira Colonial no Estuário Amazônico: Estudo Arqueológico de Engenhos dos Séculos XVIII e XIX. Tese (doutorado), PUCRS, Porto Alegre.

MELO, M. S.

2007 Geofísica aplicada a Arqueologia. Dissertação (mestrado), UFPA

MORAIS, J. L.

1983 A Utilização dos Afloramentos Litológicos pelo Homem Pré-Histórico Brasileiro; Análise do Tratamento da Matéria-Prima. São Paulo: Coleção Museu Arqueologia, v. 7

NAJJAR, R.

2005 A catequese vista pela ótica da Arqueologia: um estudo comparativo entre três igrejas jesuiticas no litoral do Brasil. Tese (doutorado), MAE/USP, São Paulo

NAJJAR, R. E DUARTE, M. C. C.

2002 O Manual de Arqueologia Histórica em Projeto de Restauração. Rio de Janeiro: Projeto Monumenta/Iphan

NEVES, W. A. E PILÓ, L. B.

2008 O Povo de Luzia: em busca dos primeiros americanos. São Paulo: Globo

OLIVEIRA, E.

2005 Aspectos da interação cultural entre os grupos ceramistas pré-coloniais do médio curso do rio Tocantins. Dissertação (mestrado), MAE/USP, São Paulo

$\mathrm{PAÇO}, \mathrm{A}$.

1960 Castro de Vila Nova de S. Pedro XII: Alguns objectos de osso e marfim. Zephyrus, Salamanca, 11: 107-117. 
PEREIRA, E.; LOPES, M. E NUNES, F.

2011 O Desenvolvimento Científico e o Coleccionismo Privado: Redes Intelectuais e Circulação do Conhecimento Científico (Arqueologia e Antropologia em Portugal - finais do século XIX e primeira metade do século XX). Congresso Luso-Brasileiro de História das Ciências, suporte CD, 2011: 1338-1351.

PEREIRA, F. I. P. S.

2011 Archaeometallurgical Study of Artefacts From Castro de Vila Nova de São Pedro (Azambuja Portugal). Dissertação (mestrado), FCT, Lisboa

PLENS, C.

2002 Terra, madeira e ferro: a Arqueologia na São Paulo Oitocentista. Dissertação (mestrado), MAE/USP, São Paulo

POLITIS, G. G.

2003 The Theoretical Landscape and the methodological development of archaeology in Latin America. American Antiquity, v. 68, n. 2: 245-272

PROUS, A.

1992 Arqueologia Brasileira. Belo Horizonte: UFMG.

1997 O povoamento da América visto do Brasil: uma perspectiva crítica. Revista USP, São Paulo, 34: 8-21

REIS, J. A.

2003 Não pensa muito que dói: um palimpsesto sobre teoria na Arqueologia Brasileira. Tese (doutorado), IFCH/UNICAMP

REITH, F.

2007 Memória da antropologia no Sul do Brasil. Horizontes Antropológicos, v. 13, n. 28: 421-427.

RODRIGUES, $\mathrm{M}$.

2010 Patrimônio industrial, entre o fetiche e a memória. USJT - Arq.Urb., n. 3: 31-41

ROHR, J. A. E ANDREATTA, M. D.

1969 O Sítio Arqueológico da Armação do Sul (Nota prévia). Pesquisas, Antropologia, n. 20: 135-138.

SILVA, V, M.

2001 A construção da política cultural no regime mi litar: concepções, diretrizes e programas (1974 - 1978). Dissertação (mestrado), FFLCH/ VELHO, G. USP, São Paulo

2008 Individualismo e cultural: notas para uma antropologia da sociedade contemporânea. Rio de Janeiro: Jorge Zahar
SAID, E.

2003 Representações do intelectual. São Paulo: Cia das Letras

SOUTH, S.

1977 Method and Theory in Historical Archaeology. Academic Press, New York

SCHMITZ, P. I.; BARBOSA, A. S.; JACOBUS, A. J. RIBEIRA, M. B.

1989 Arqueologia nos cerrados do Brasil Central. Serranópolis I. São Leopoldo: Unisinos.

SCHMITZ, P. I. E BARBOSA, A. S.

1985 Horticultores pré-históricos do estado de Goiás. São Leopoldo: Instituto Anchietano de Pesquisas.

SCHMITZ, P. I. E VERARDI, I.

1995-1996 A pesquisa arqueológica no Instituto Anchietano de Pesquisas/ UNISINOS. Coleção Arqueologia, Edipucrs, n. 1, v. 1: $167-178$

SCHMITZ, P. I.; DE MASI, M. A.; VERARDI, I.; LAVINA, R. E JACOBUS, A. L.

1993 Escavações arqueológicas do Pe. João Alfredo Rohr. O sítio arqueológico da Armação do Sul. Pesquisas, Antropologia, n. 48

SCHUYLER, R. L.

1978 Historical Archaeology: A Guide to Substantive and Theoretical Contributions. Baywood Pub Co

SILVA, V. M.

2001 A construção da política cultural no regime militar: concepções, diretrizes e programas (1974-1978). Dissertação (mestrado), FFL$\mathrm{CH} / \mathrm{USP}$

SOCIETÉ DES AMERICANISTES

1963 Actes de la société. Journal de la Soiceté des Américanistes, tome 52: 325-327

SOUZA, M. L.

1997 Arqueologia Histórica Aplicada ao reconhecimento de uma Fazenda Colonial do século XVIII. Dissertação (mestrado), FFLCH/ USP, São Paulo

SOUZA, R. A.

2010 Louça branca para a Paulicéia: Arqueolo gia Histórica da Fábrica de Louça Santa Catarina - IRFM - São Paulo e a produção da faiança fina nacional (1913-1937). Dissertação (mestrado), MAE/USP, São Paulo

SYMANSKI, L. C.

2009 Arqueologia Histórica no Brasil: uma revisão dos últimos 20 anos. MORALES, W. F. e MOI, F. P. (org.) Cenários Regionais em Arqueologia Brasileira. São Paulo: Annablume 
TENÓRIO, C.

2004 Identidade cultural e origem dos sambaquis. Revista do Museu de Arqueologia e Etnologia, São Paulo, 14: 169-178

\section{THOMAZ, R.}

1996 Arqueologia da influência jesuítica no Baixo Paranapanema - o estudo do sítio Taquaruçu. Dissertação (mestrado), FFLCH/USP, São Paulo

TOMIYAMA, N.

2002 Sítio Taboão - Arqueologia Histórica do Vale do Parateí - Mogi das Cruzes - SP. Dissertação (mestrado), MAE/USP, São Paulo

UCHOA, D. P. E GARCIA, C. R.

1986 Ilha do Casqueirinho, estado de São Paulo, Brasil. Dados arqueológicos preliminares. Revista do CEPA, 5: 43-54.

\section{VASCONCELLOS, J. L.}

1964 Contos populares e lendas, v. 2

WICHERS, C. M. A.

2012 Patrimônio arqueológico paulista: proposições e provocações museológicas. Tese (doutorado), MAE/USP, São Paulo
WÜST, I. E BARRETO, C.

1999 The ring villages of central Brazil: a challenge for Amazonian archaeology. Latin American Antiquity, 10(1): 3-23.

ZANETTINI, P. E.

1998 Calçada do Lorena, o caminho do mar. Dissertação (mestrado), FFLCH/USP, São Paulo

2005 Mamelucos e seus palácios de barro: o cotidiano das casas bandeiristas. Tese (doutorado), MAE/USP, São Paulo

ZANETTINI, P. E. E CAZZETTA, M.

1993 Arqueologia histórica no Brasil: ela existe, mas você desconhece. São Paulo. p. 6. Manuscrito inédito.

ZARANKIN, A. E SALERNO, M. A.

2007 El sur por el sur: una revisión sobre la historia y el desarollo de la arqueologia histórica em América meridional. Vestígios, UFMG, v. 1, n. 1: 17-48

ZEQUINI, A.

2007 Arqueologia de uma fábrica de ferro: morro de Araçoiaba séculos XVI-XVIII. Tese (doutorado), MAE/USP, São Paulo 